\title{
Absolute and Relative Binding Affinity of Cucurbit[7]uril Toward a Series of Cationic Guests
}

\author{
Supporting Information \\ by Liping Cao and Lyle Isaacs* \\ Department of Chemistry and Biochemistry, University of Maryland, College Park, MD 20742
}

${ }^{1} \mathrm{H}$ NMR spectra recorded for selected $\mathrm{CB}[7] \cdot$ guest complexes

Job plots by NMR experiments........................................................................... 20-21

Sample Determination of $\mathrm{K}_{\text {rel }}$ for the Competition Between $\mathbf{1}$ and $\mathbf{4}$ for $\mathrm{CB}[7] \ldots \ldots \ldots \ldots \ldots \ldots \ldots . . . . . . . . . .22$

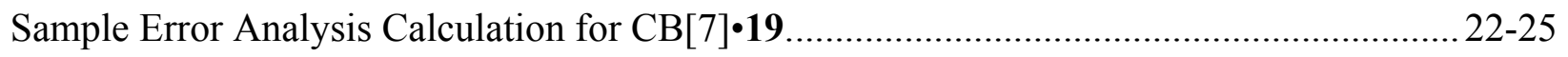

Selected ${ }^{1} \mathrm{H}$ NMR spectra from the $\mathrm{K}_{\mathrm{a}}$ and $\mathrm{K}_{\text {rel }}$ measurements ........................................26-43

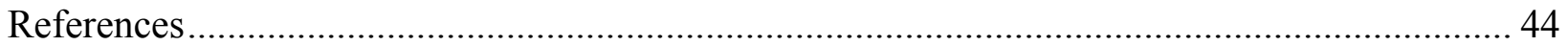


${ }^{1}$ H NMR spectra recorded for selected $\mathrm{CB}[7] \cdot$ guest complexes

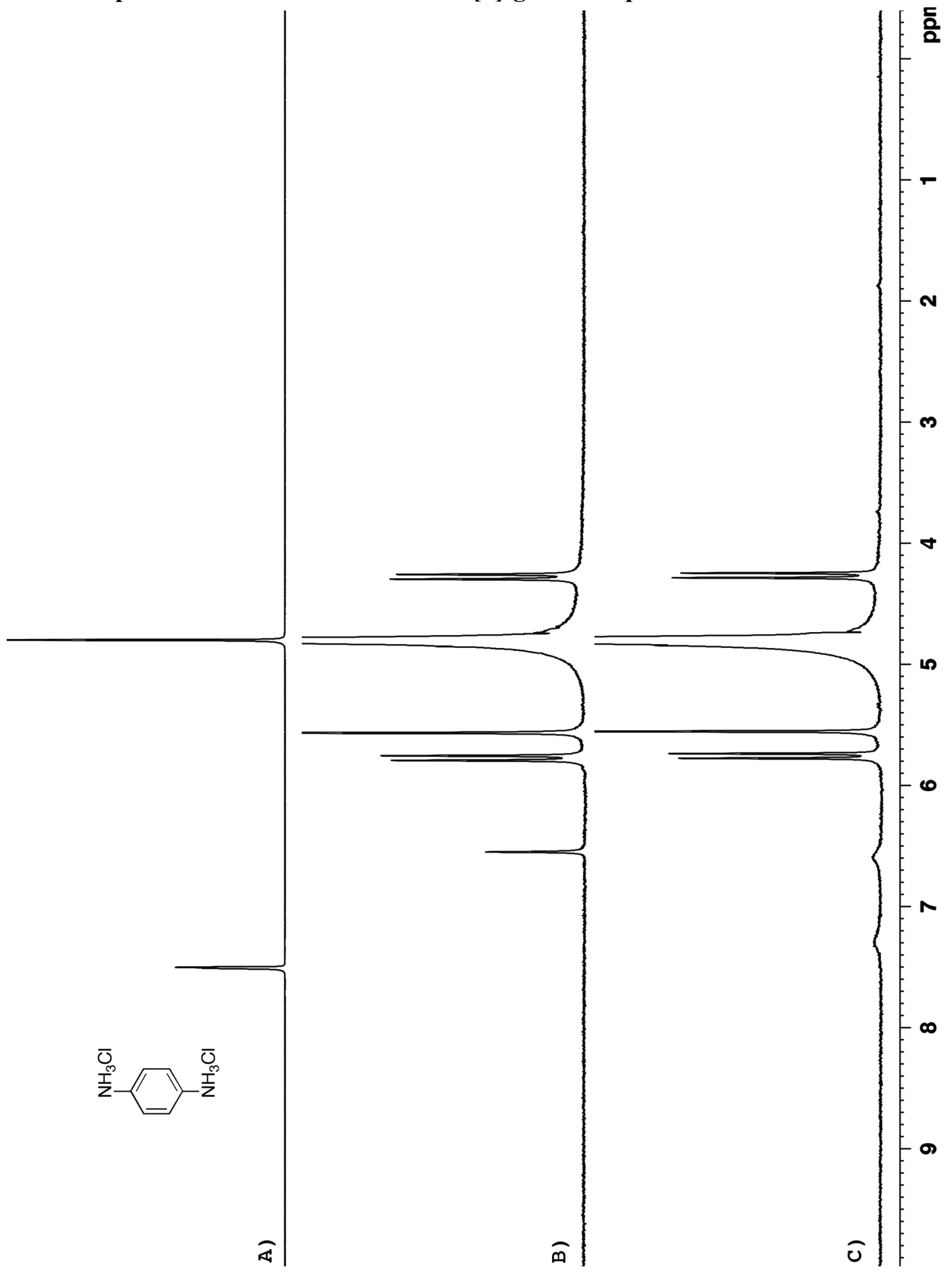

Figure S1. $\quad{ }^{1} \mathrm{H}$ NMR spectra recorded $\left(\mathrm{D}_{2} \mathrm{O}, 400 \mathrm{MHz}, \mathrm{RT}\right)$ for: a) $\mathbf{1}(0.25 \mathrm{mM})$, b) a mixture of $\mathrm{CB}$ [7] $(0.25 \mathrm{mM})$ and $1(0.25 \mathrm{mM})$, and c) a mixture of $\mathrm{CB}$ [7] $(0.25 \mathrm{mM})$ and $1(0.5 \mathrm{mM})$. 


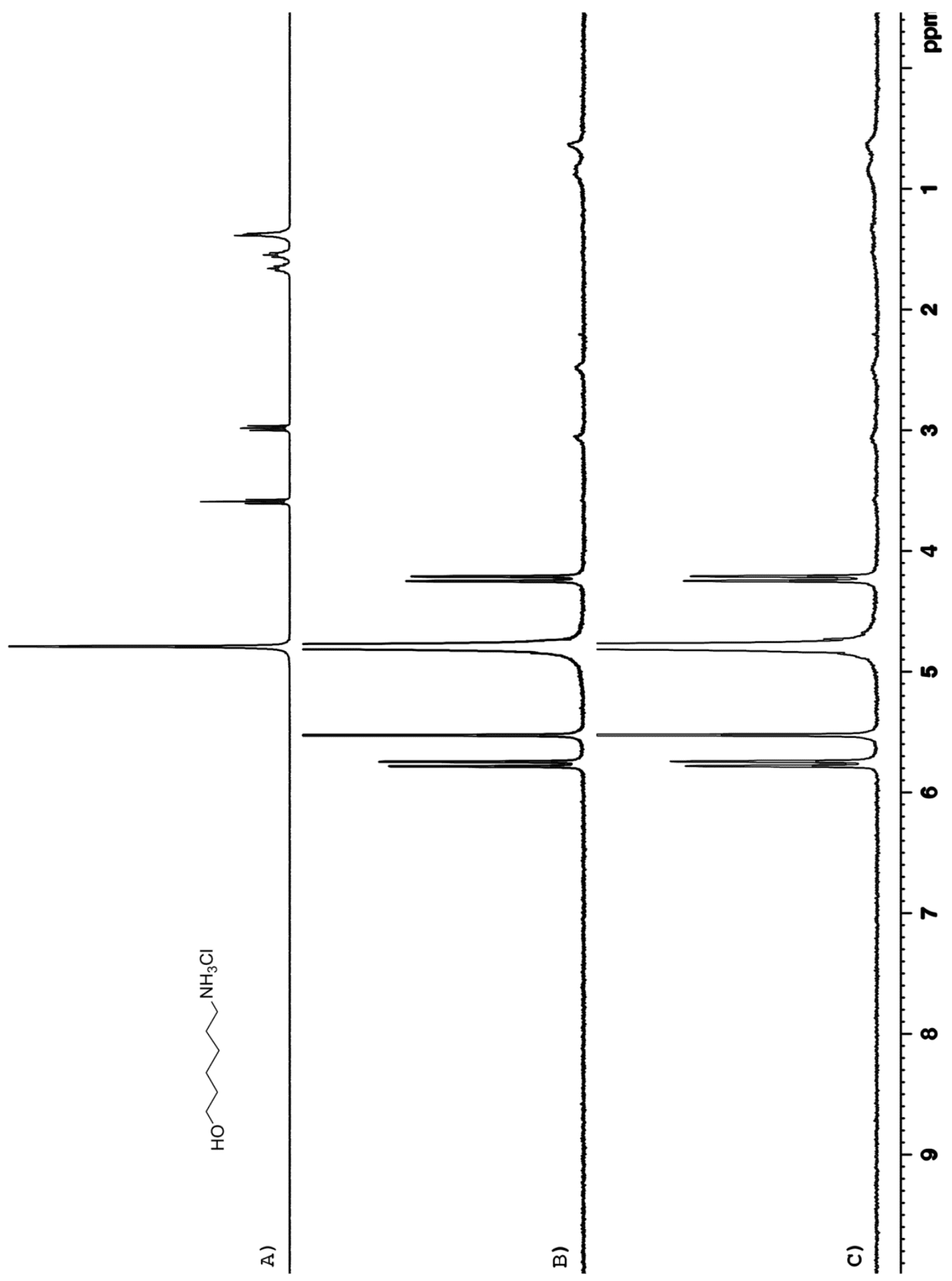

Figure S2. $\quad{ }^{1} \mathrm{H}$ NMR spectra recorded $\left(\mathrm{D}_{2} \mathrm{O}, 400 \mathrm{MHz}, \mathrm{RT}\right)$ for: a) $2(0.25 \mathrm{mM})$, b) a mixture of $\mathrm{CB}[7](0.25 \mathrm{mM})$ and $2(0.25 \mathrm{mM})$, and c) a mixture of $\mathrm{CB}[7](0.25 \mathrm{mM})$ and $2(0.5 \mathrm{mM})$. 


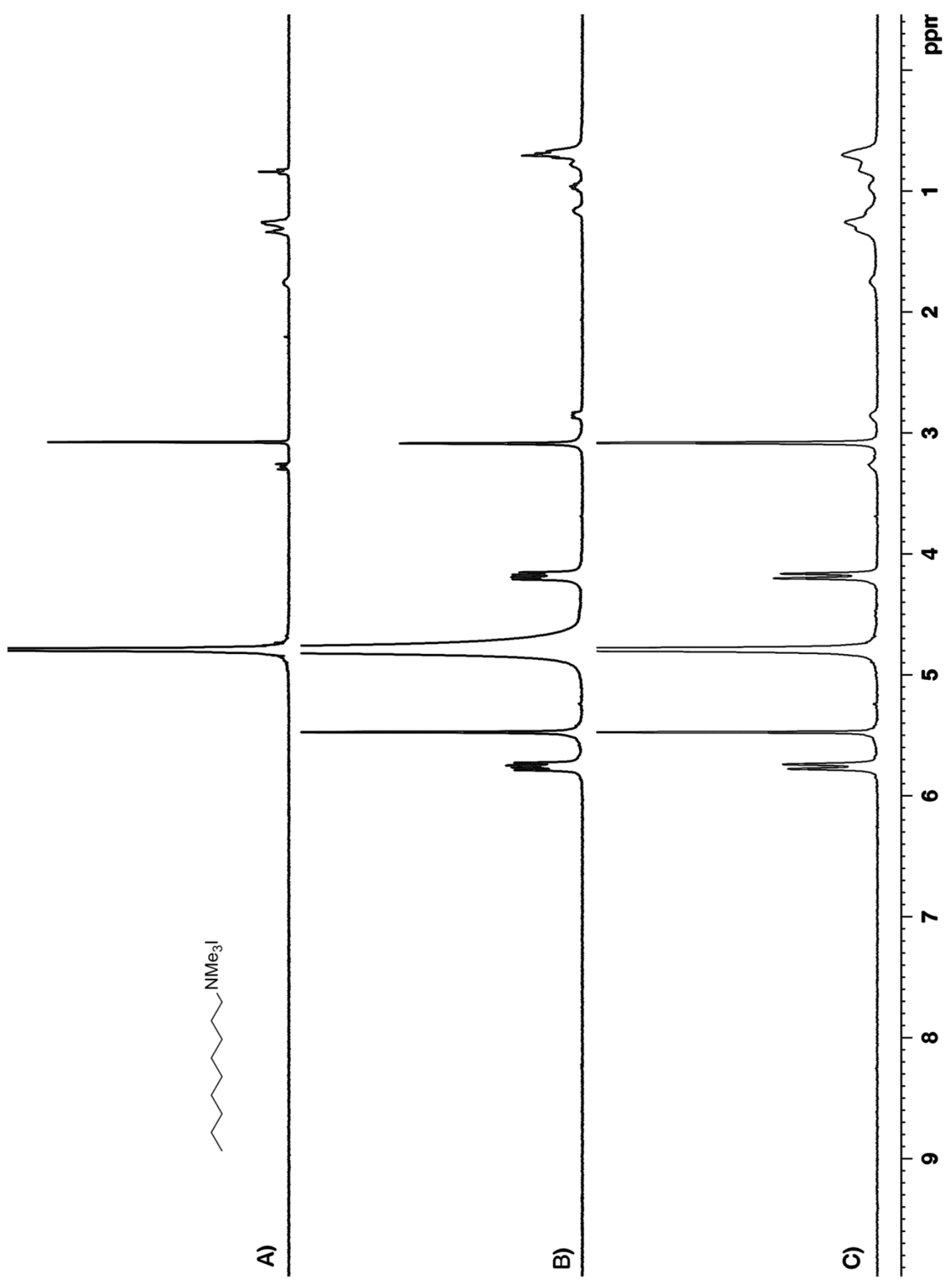

Figure S3. $\quad{ }^{1} \mathrm{H}$ NMR spectra recorded $\left(\mathrm{D}_{2} \mathrm{O}, 400 \mathrm{MHz}, \mathrm{RT}\right)$ for: a) $3(0.25 \mathrm{mM})$, b) a mixture of $\mathrm{CB}$ [7] $(0.25 \mathrm{mM})$ and $\mathbf{3}(0.25 \mathrm{mM})$, and c) a mixture of $\mathrm{CB}[7](0.25 \mathrm{mM})$ and $\mathbf{3}(0.5 \mathrm{mM})$. 


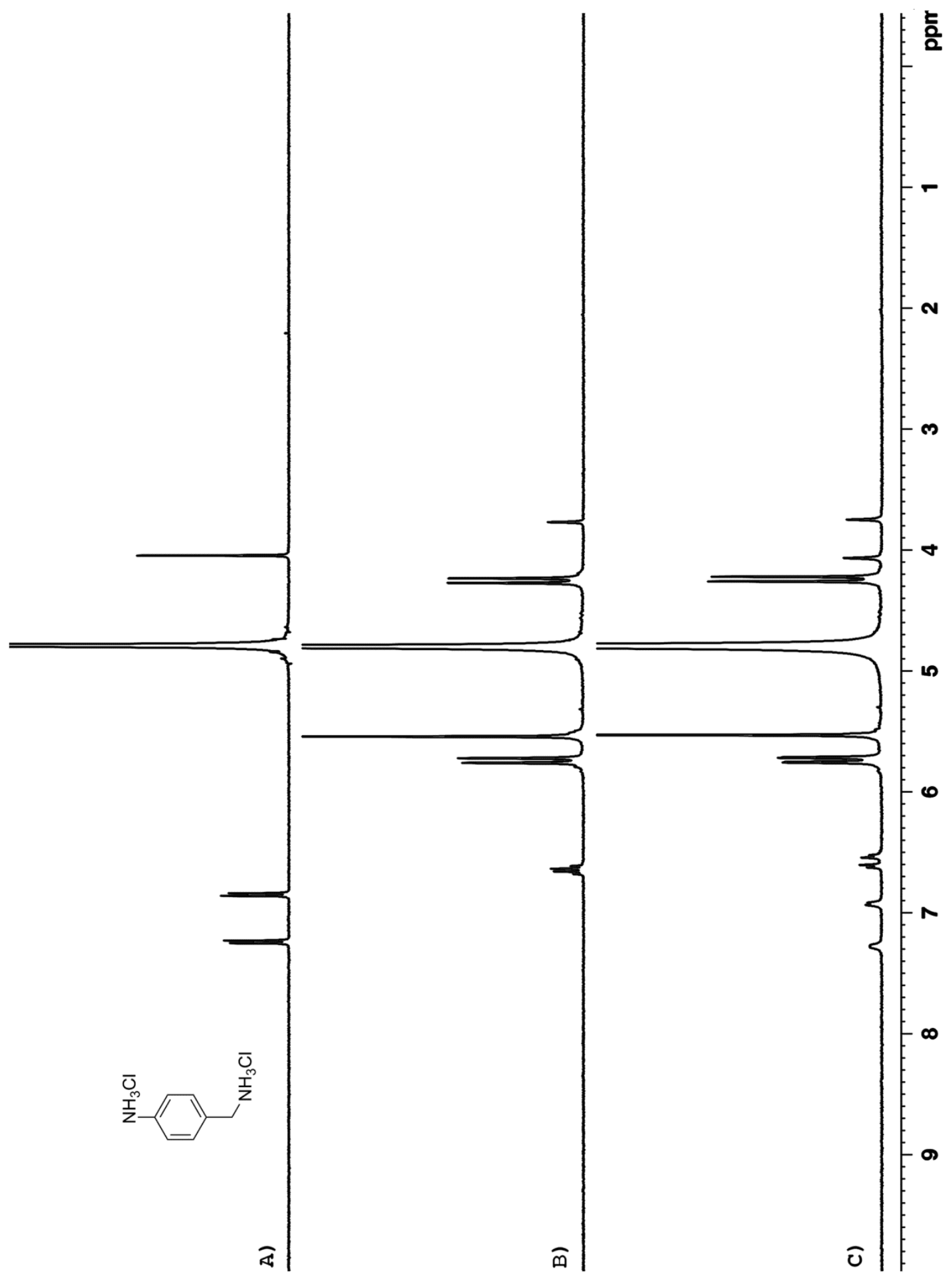

Figure S4. $\quad{ }^{1} \mathrm{H}$ NMR spectra recorded $\left(\mathrm{D}_{2} \mathrm{O}, 400 \mathrm{MHz}, \mathrm{RT}\right)$ for: a) $4(0.25 \mathrm{mM})$, b) a mixture of $\mathrm{CB}$ [7] $(0.25 \mathrm{mM})$ and $4(0.25 \mathrm{mM})$, and c) a mixture of $\mathrm{CB}[7](0.25 \mathrm{mM})$ and $4(0.5 \mathrm{mM})$. 


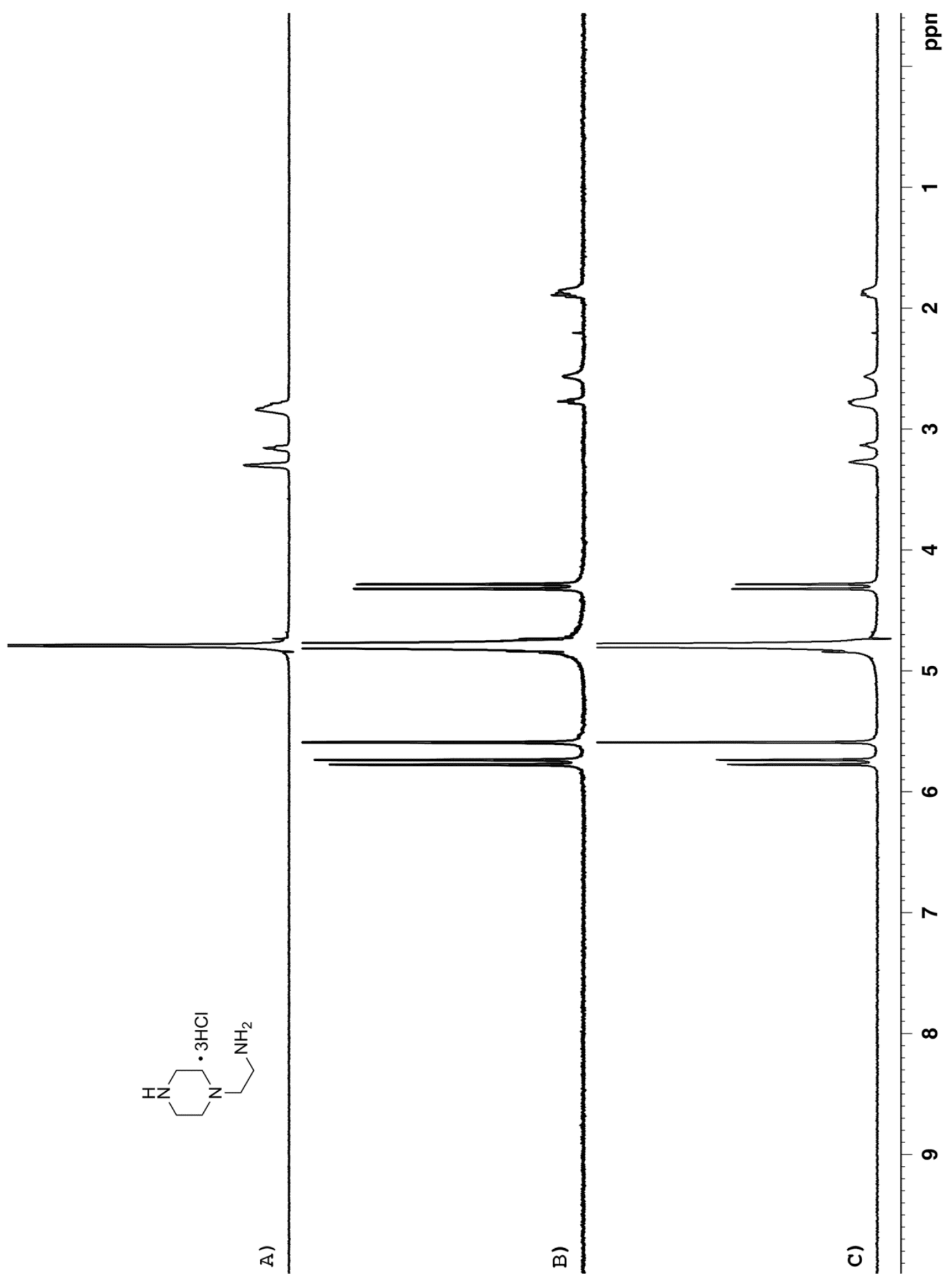

Figure S5. ${ }^{1} \mathrm{H}$ NMR spectra recorded $\left(\mathrm{D}_{2} \mathrm{O}, 400 \mathrm{MHz}, \mathrm{RT}\right)$ for: a) $5(0.25 \mathrm{mM})$, b) a mixture of $\mathrm{CB}$ [7] $(0.25 \mathrm{mM})$ and $\mathbf{5}(0.25 \mathrm{mM})$, and c) a mixture of $\mathrm{CB}[7](0.25 \mathrm{mM})$ and $\mathbf{5}(0.5 \mathrm{mM})$. 


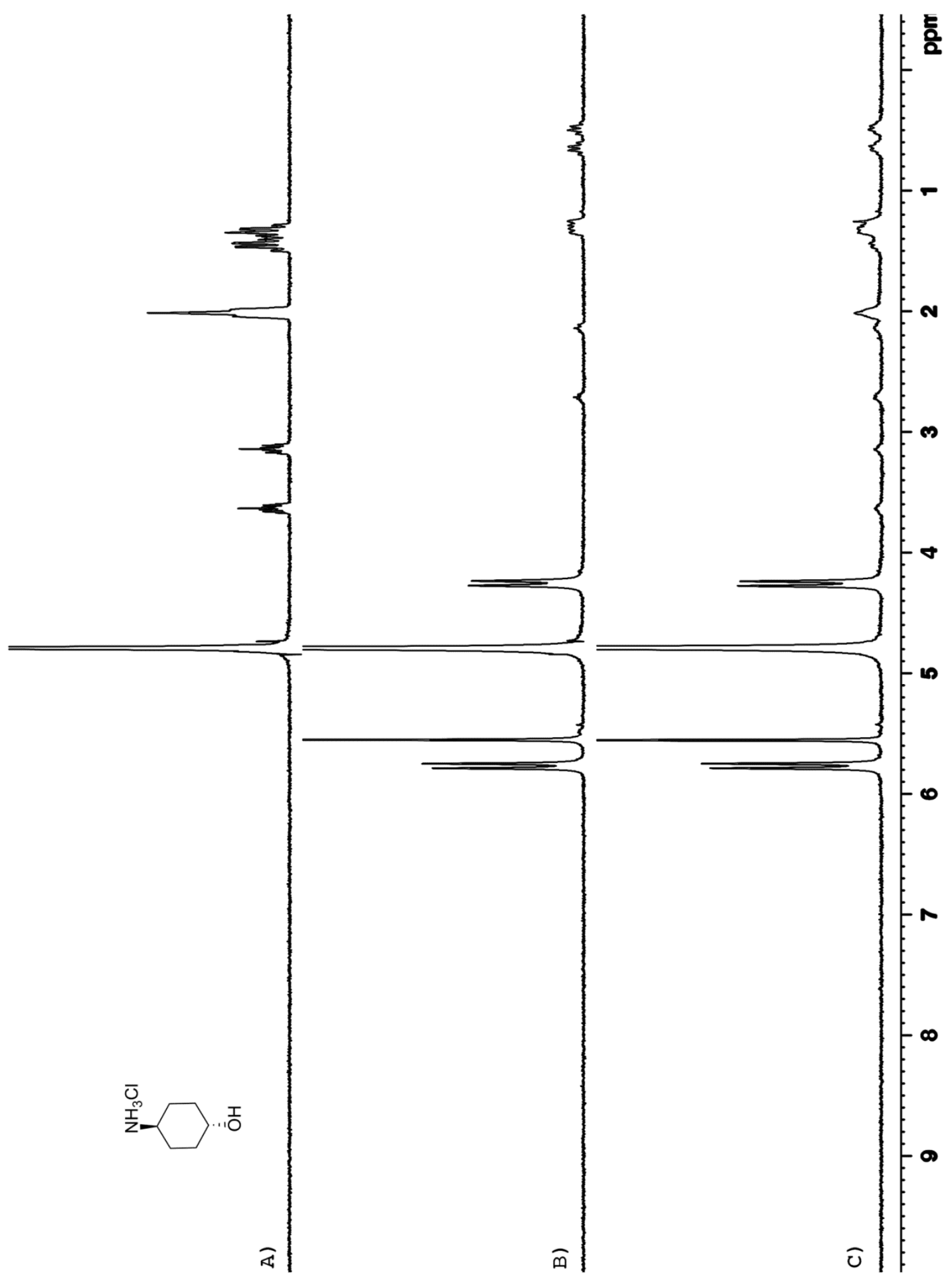

Figure S6. ${ }^{1} \mathrm{H}$ NMR spectra recorded $\left(\mathrm{D}_{2} \mathrm{O}, 400 \mathrm{MHz}, \mathrm{RT}\right)$ for: a) $6(0.25 \mathrm{mM})$, b) a mixture of $\mathrm{CB}$ [7] $(0.25 \mathrm{mM})$ and $6(0.25 \mathrm{mM})$, and c) a mixture of $\mathrm{CB}[7](0.25 \mathrm{mM})$ and $6(0.5 \mathrm{mM})$. 


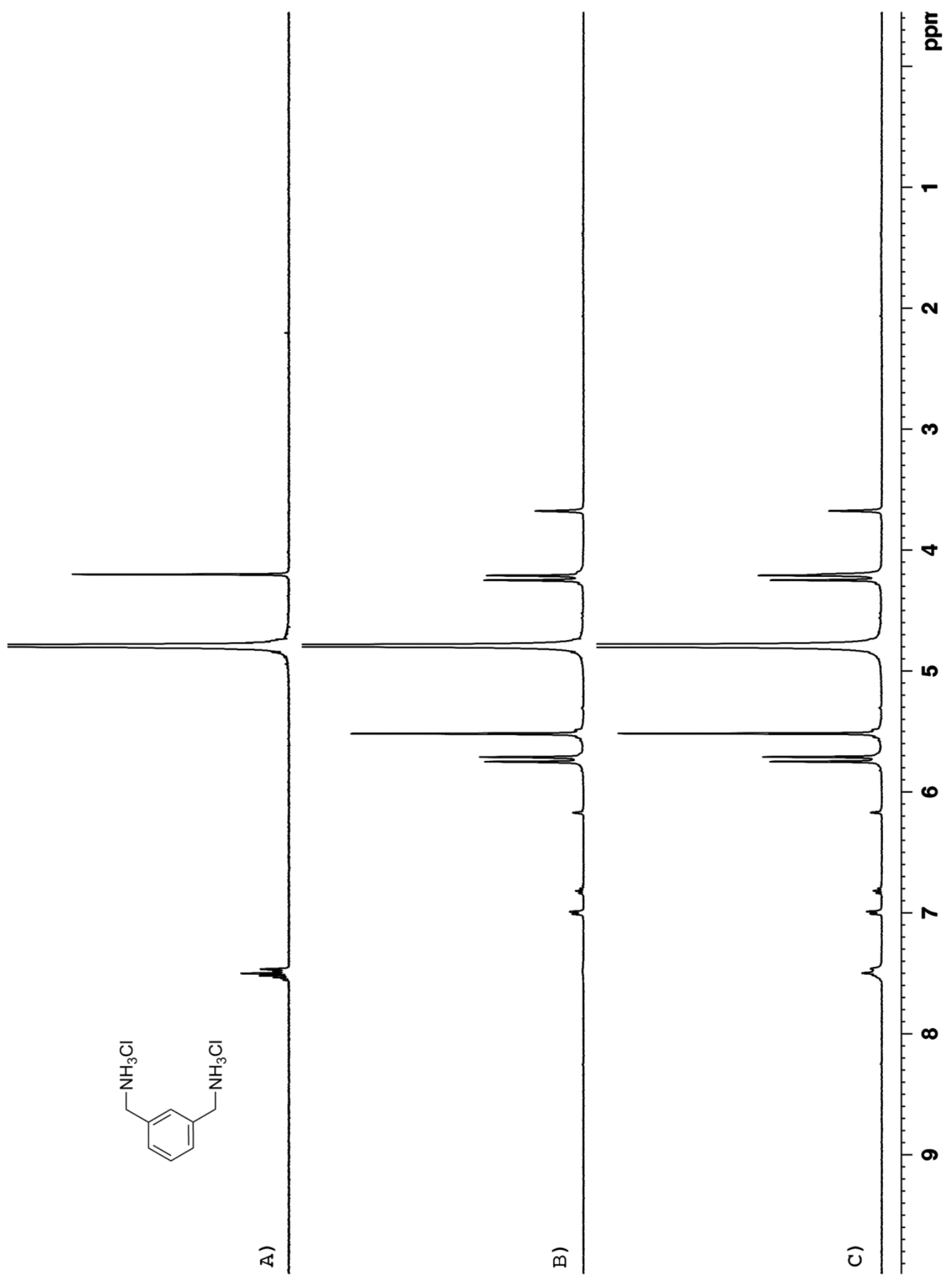

Figure S7. ${ }^{1} \mathrm{H}$ NMR spectra recorded $\left(\mathrm{D}_{2} \mathrm{O}, 400 \mathrm{MHz}, \mathrm{RT}\right)$ for: a) $8(0.25 \mathrm{mM})$, b) a mixture of $\mathrm{CB}[7](0.25 \mathrm{mM})$ and $8(0.25 \mathrm{mM})$, and c) a mixture of $\mathrm{CB}[7](0.25 \mathrm{mM})$ and $8(0.5 \mathrm{mM})$. 


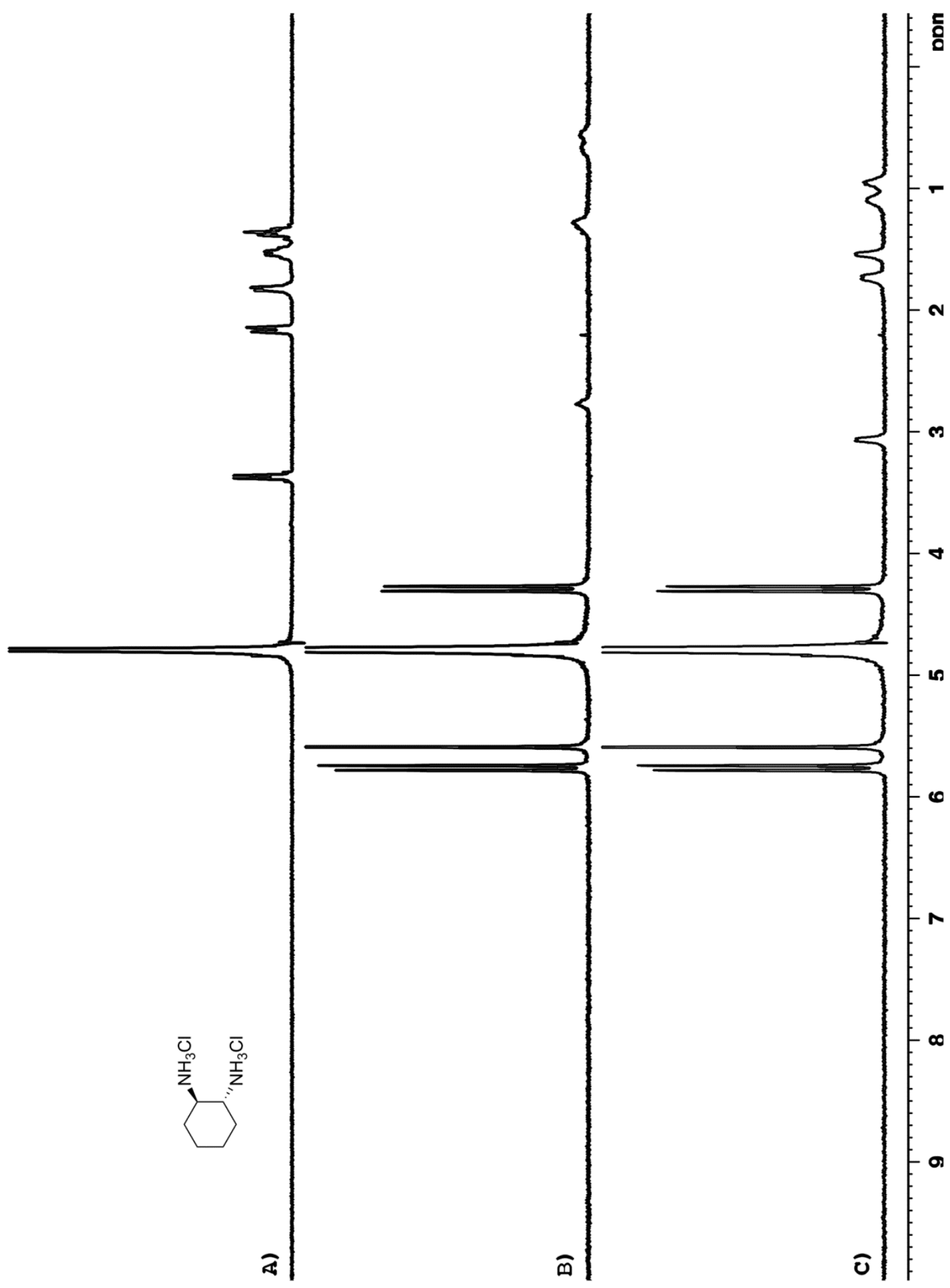

Figure S8. $\quad{ }^{1} \mathrm{H}$ NMR spectra recorded $\left(\mathrm{D}_{2} \mathrm{O}, 400 \mathrm{MHz}, \mathrm{RT}\right)$ for: a) $9(0.25 \mathrm{mM})$, b) a mixture of $\mathrm{CB}$ [7] $(0.25 \mathrm{mM})$ and $9(0.25 \mathrm{mM})$, and c) a mixture of $\mathrm{CB}$ [7] $(0.25 \mathrm{mM})$ and $9(0.5 \mathrm{mM})$. 


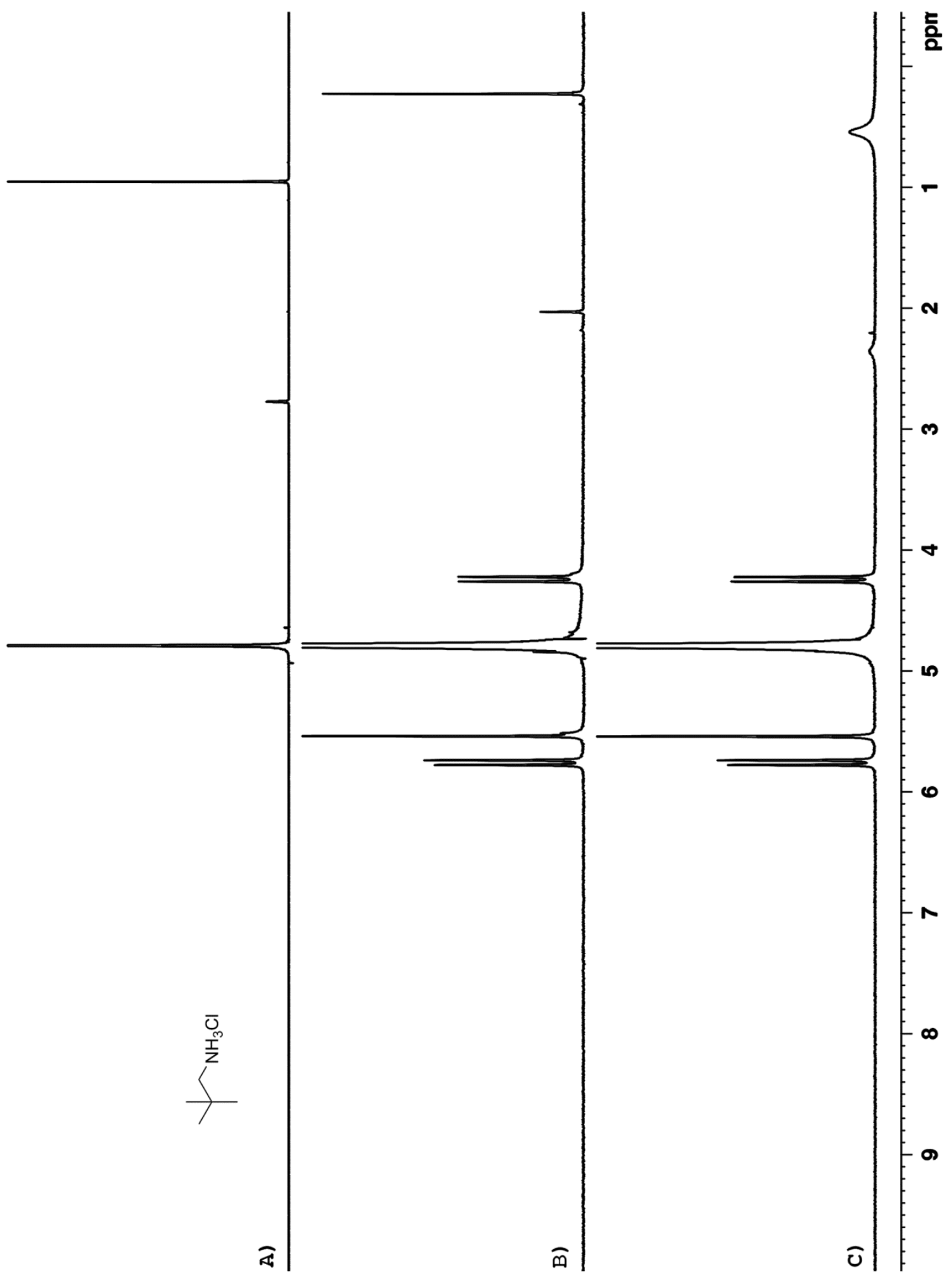

Figure S9. $\quad{ }^{1} \mathrm{H}$ NMR spectra recorded $\left(\mathrm{D}_{2} \mathrm{O}, 400 \mathrm{MHz}, \mathrm{RT}\right)$ for: a) $\mathbf{1 0}(0.25 \mathrm{mM})$, b) a mixture of $\mathrm{CB}$ [7] $(0.25 \mathrm{mM})$ and $10(0.25 \mathrm{mM})$, and c) a mixture of $\mathrm{CB}$ [7] $(0.25 \mathrm{mM})$ and $10(0.5 \mathrm{mM})$. 


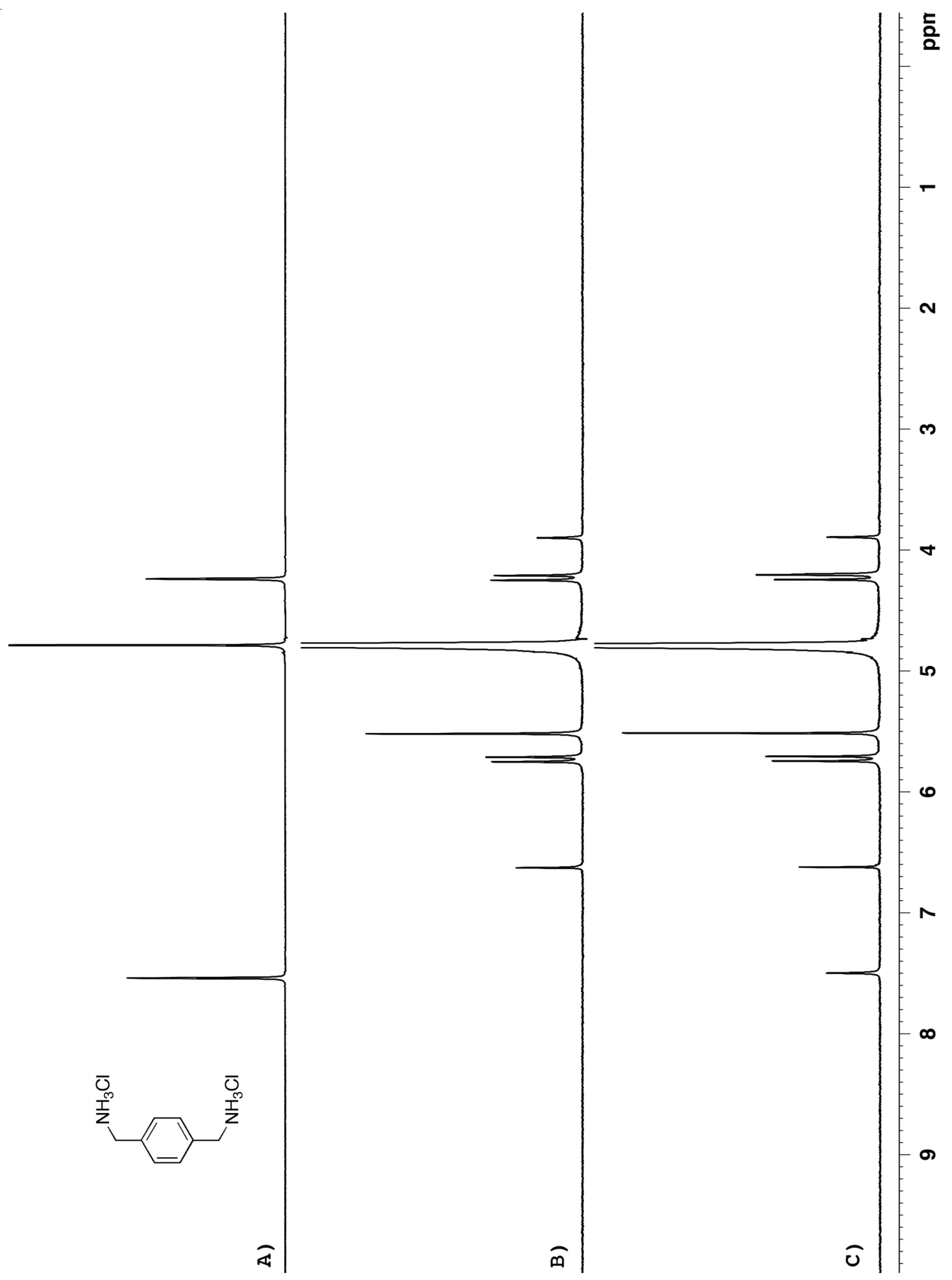

Figure S10. $\quad{ }^{1} \mathrm{H}$ NMR spectra recorded $\left(\mathrm{D}_{2} \mathrm{O}, 400 \mathrm{MHz}, \mathrm{RT}\right)$ for: a) $11(0.25 \mathrm{mM})$, b) a mixture of $\mathrm{CB}$ [7] $(0.25 \mathrm{mM})$ and $11(0.25 \mathrm{mM})$, and $\mathrm{c})$ a mixture of $\mathrm{CB}$ [7] $(0.25 \mathrm{mM})$ and 11 $(0.5 \mathrm{mM})$. 


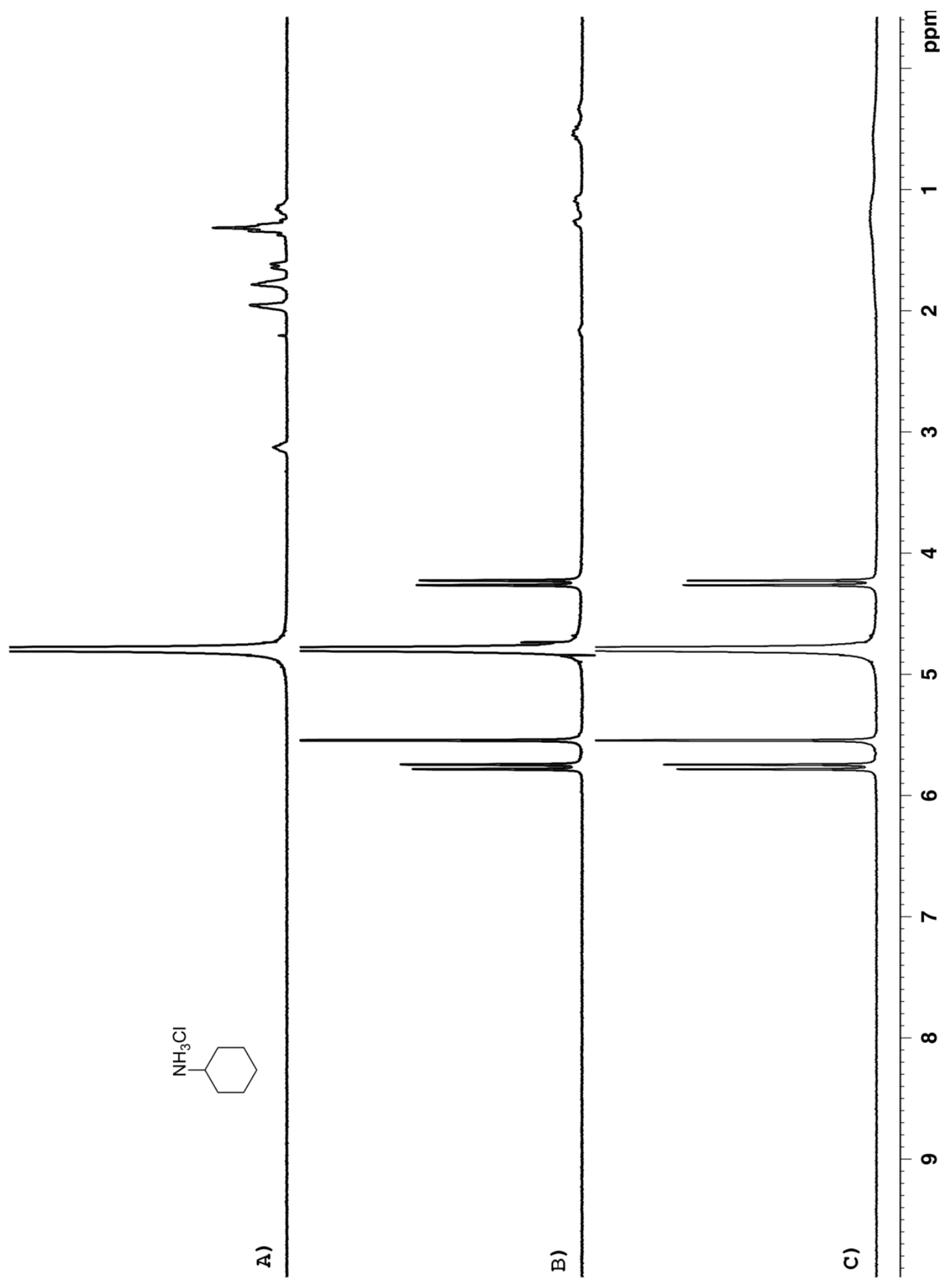

Figure S11. ${ }^{1} \mathrm{H}$ NMR spectra recorded $\left(\mathrm{D}_{2} \mathrm{O}, 400 \mathrm{MHz}, \mathrm{RT}\right)$ for: a) $12(0.25 \mathrm{mM})$, b) a mixture of $\mathrm{CB}$ [7] $(0.25 \mathrm{mM})$ and $12(0.25 \mathrm{mM})$, and $\mathrm{c})$ a mixture of $\mathrm{CB}$ [7] $(0.25 \mathrm{mM})$ and 12 $(0.5 \mathrm{mM})$. 


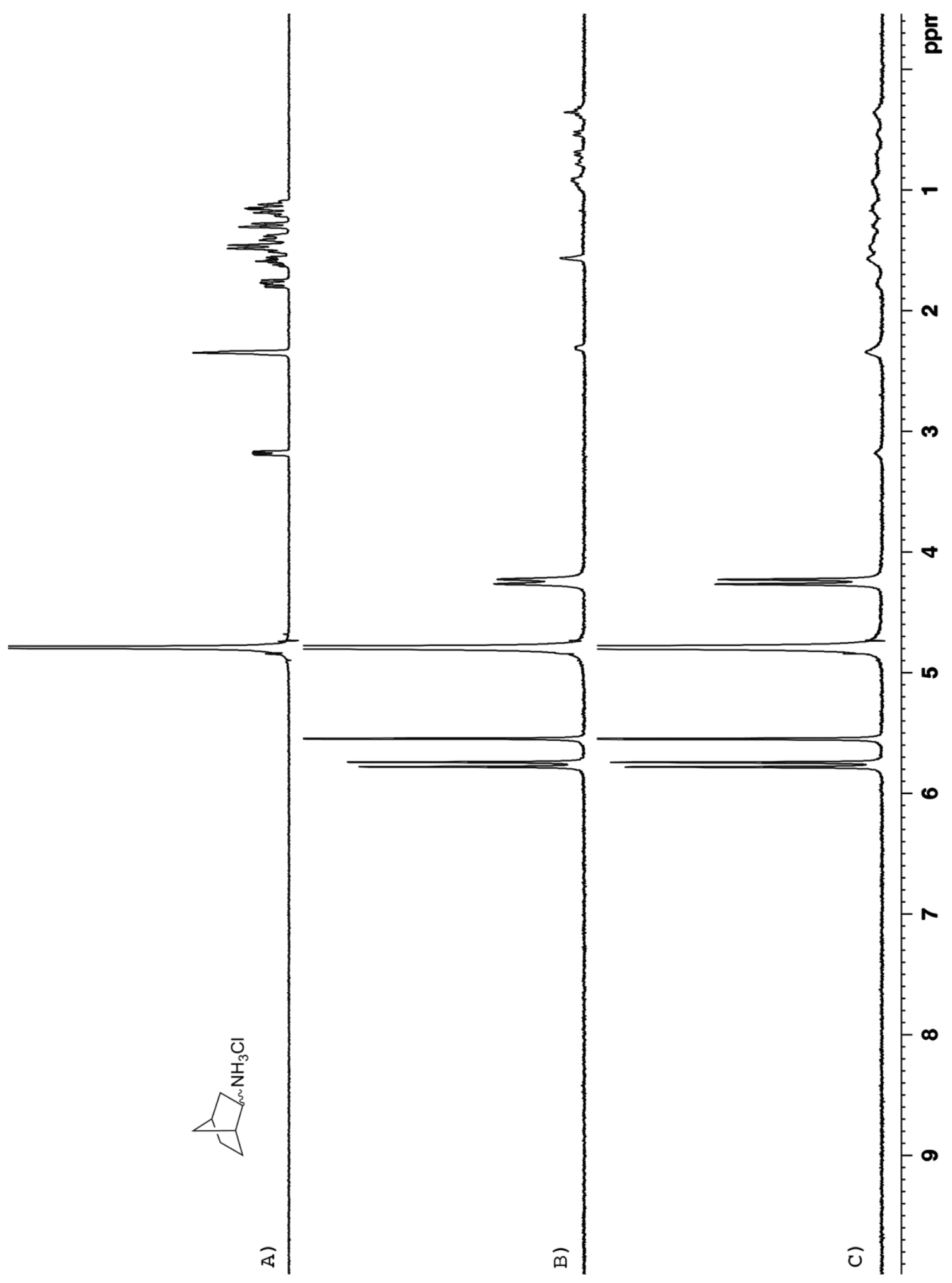

Figure S12. $\quad{ }^{1} \mathrm{H}$ NMR spectra recorded $\left(\mathrm{D}_{2} \mathrm{O}, 400 \mathrm{MHz}, \mathrm{RT}\right)$ for: a) $\mathbf{1 3}(0.25 \mathrm{mM})$, b) a mixture of $\mathrm{CB}$ [7] $(0.25 \mathrm{mM})$ and $13(0.25 \mathrm{mM})$, and $\mathrm{c})$ a mixture of $\mathrm{CB}$ [7] $(0.25 \mathrm{mM})$ and 13 $(0.5 \mathrm{mM})$. 


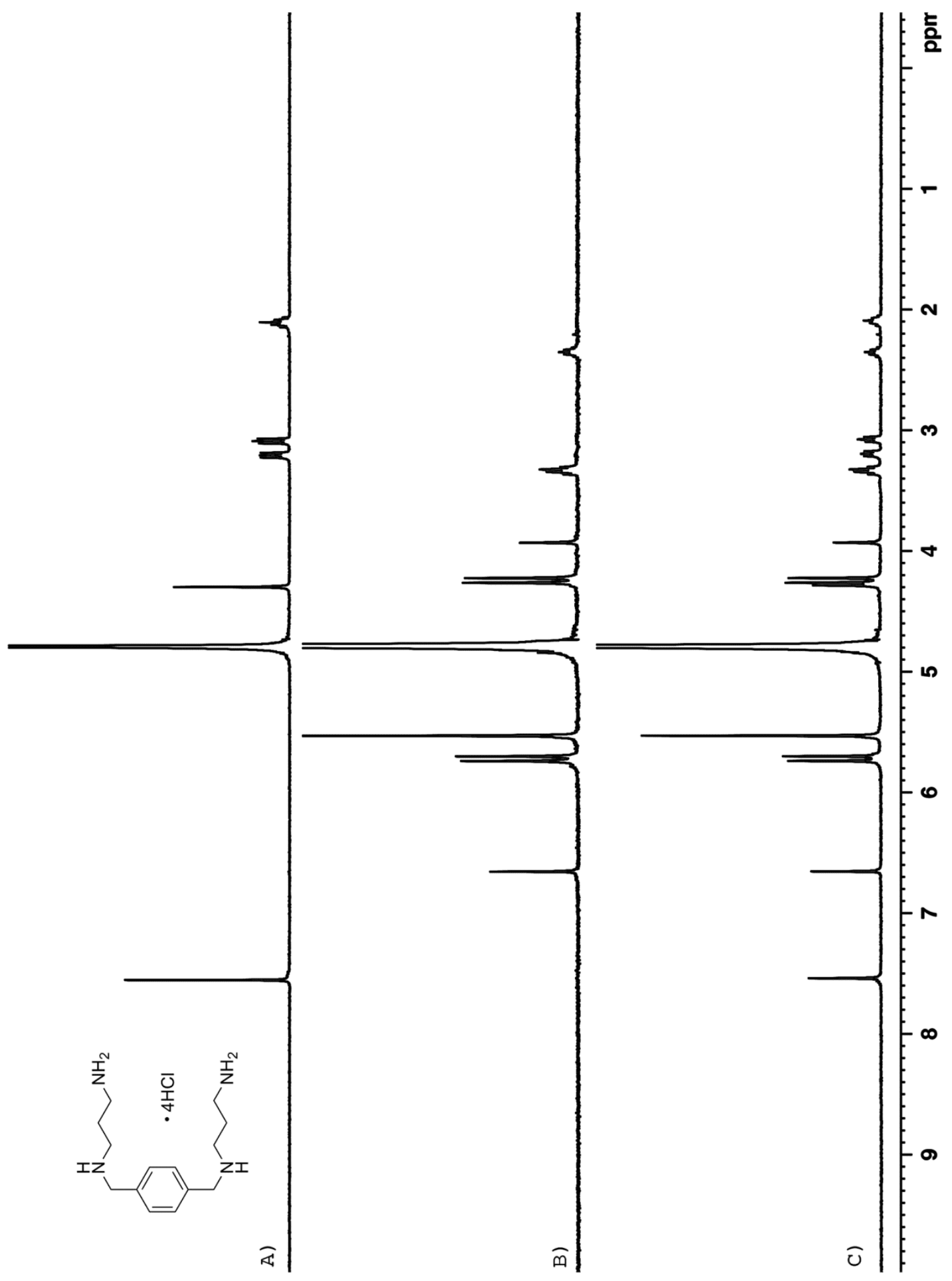

Figure S13. $\quad{ }^{1} \mathrm{H}$ NMR spectra recorded $\left(\mathrm{D}_{2} \mathrm{O}, 400 \mathrm{MHz}, \mathrm{RT}\right)$ for: a) $14(0.25 \mathrm{mM})$, b) a mixture of $\mathrm{CB}$ [7] $(0.25 \mathrm{mM})$ and $14(0.25 \mathrm{mM})$, and $\mathrm{c})$ a mixture of $\mathrm{CB}$ [7] $(0.25 \mathrm{mM})$ and 14 $(0.5 \mathrm{mM})$. 


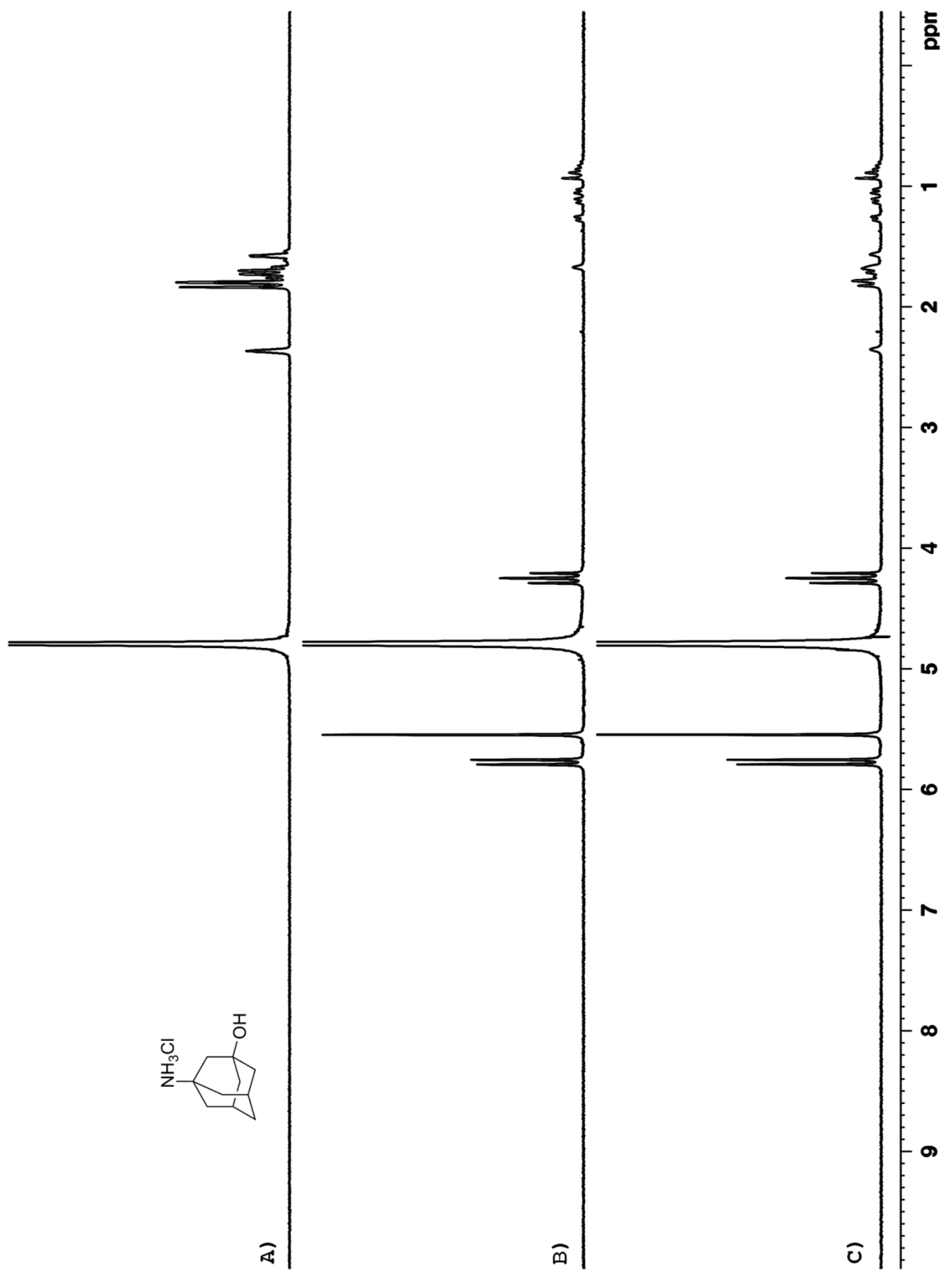

Figure S14. $\quad{ }^{1} \mathrm{H}$ NMR spectra recorded $\left(\mathrm{D}_{2} \mathrm{O}, 400 \mathrm{MHz}, \mathrm{RT}\right)$ for: a) $15(0.25 \mathrm{mM})$, b) a mixture of $\mathrm{CB}$ [7] $(0.25 \mathrm{mM})$ and $15(0.25 \mathrm{mM})$, and $\mathrm{c})$ a mixture of $\mathrm{CB}$ [7] $(0.25 \mathrm{mM})$ and 15 $(0.5 \mathrm{mM})$. 


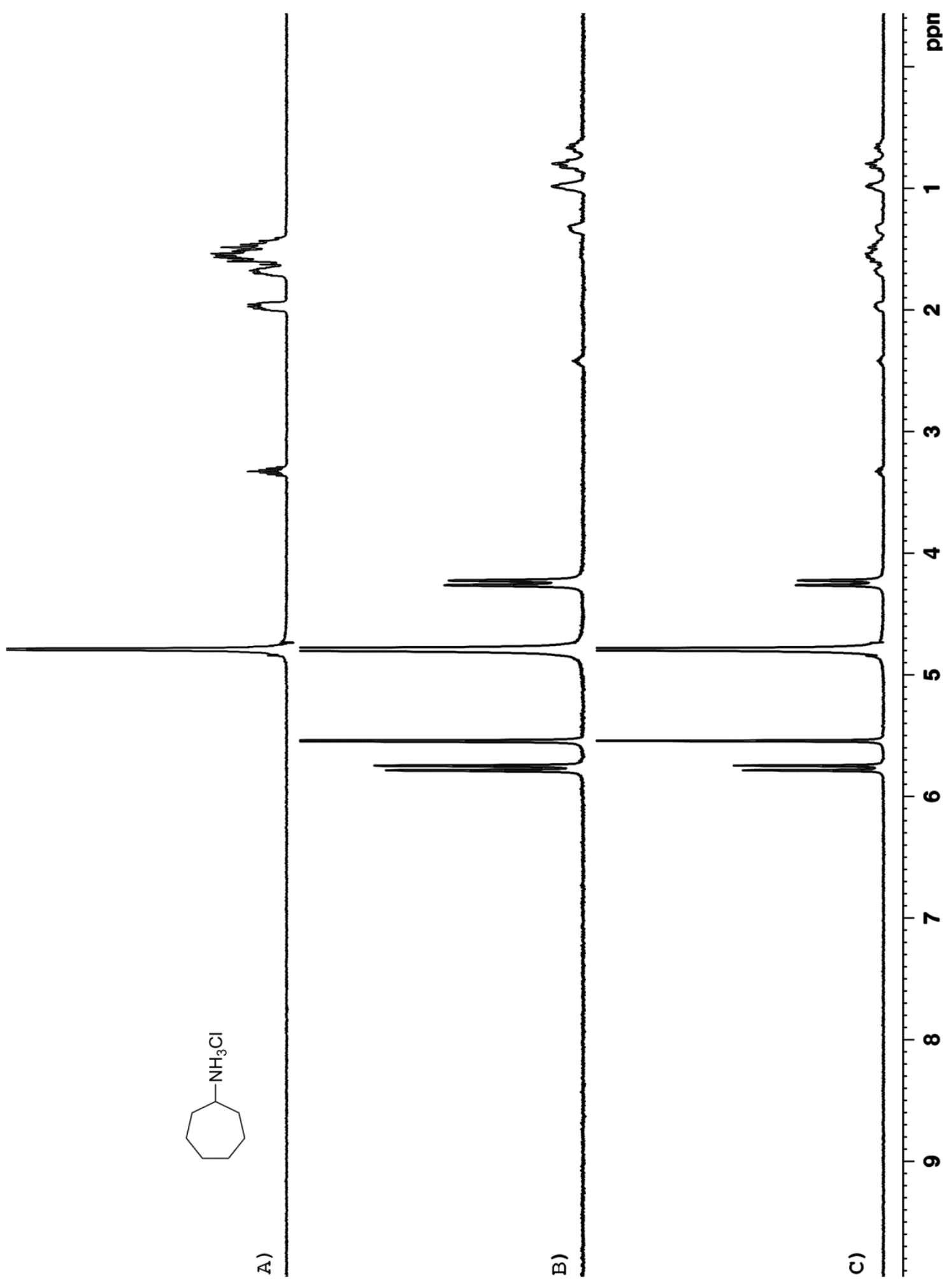

Figure S15. $\quad{ }^{1} \mathrm{H}$ NMR spectra recorded $\left(\mathrm{D}_{2} \mathrm{O}, 400 \mathrm{MHz}, \mathrm{RT}\right)$ for: a) $\mathbf{1 6}(0.25 \mathrm{mM})$, b) a mixture of $\mathrm{CB}$ [7] $(0.25 \mathrm{mM})$ and $16(0.25 \mathrm{mM})$, and $\mathrm{c})$ a mixture of $\mathrm{CB}$ [7] $(0.25 \mathrm{mM})$ and 16 $(0.5 \mathrm{mM})$. 


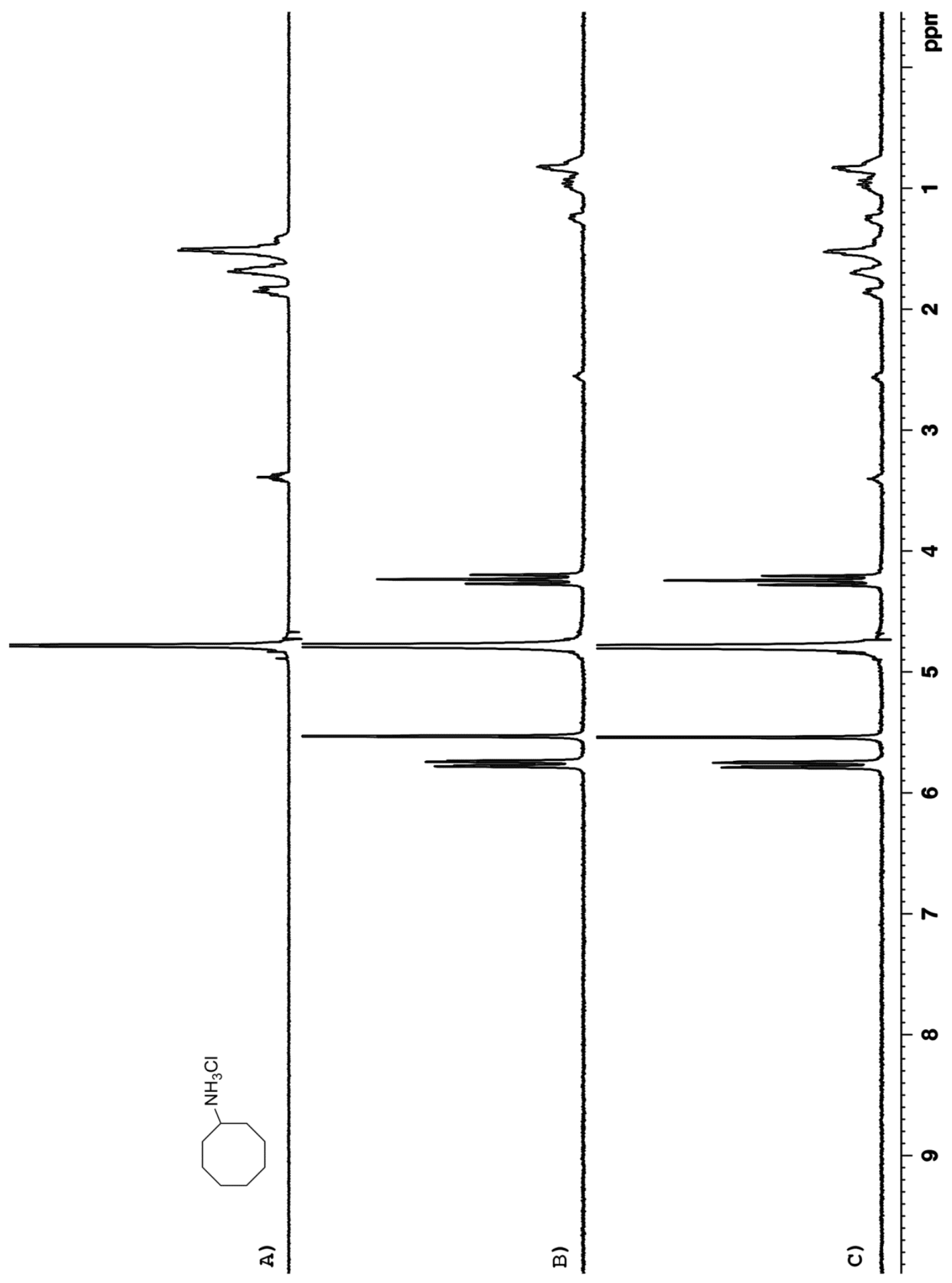

Figure S16. $\quad{ }^{1} \mathrm{H}$ NMR spectra recorded $\left(\mathrm{D}_{2} \mathrm{O}, 400 \mathrm{MHz}, \mathrm{RT}\right)$ for: a) $17(0.25 \mathrm{mM})$, b) a mixture of $\mathrm{CB}$ [7] $(0.25 \mathrm{mM})$ and $17(0.25 \mathrm{mM})$, and $\mathrm{c})$ a mixture of $\mathrm{CB}$ [7] $(0.25 \mathrm{mM})$ and 17 $(0.5 \mathrm{mM})$. 


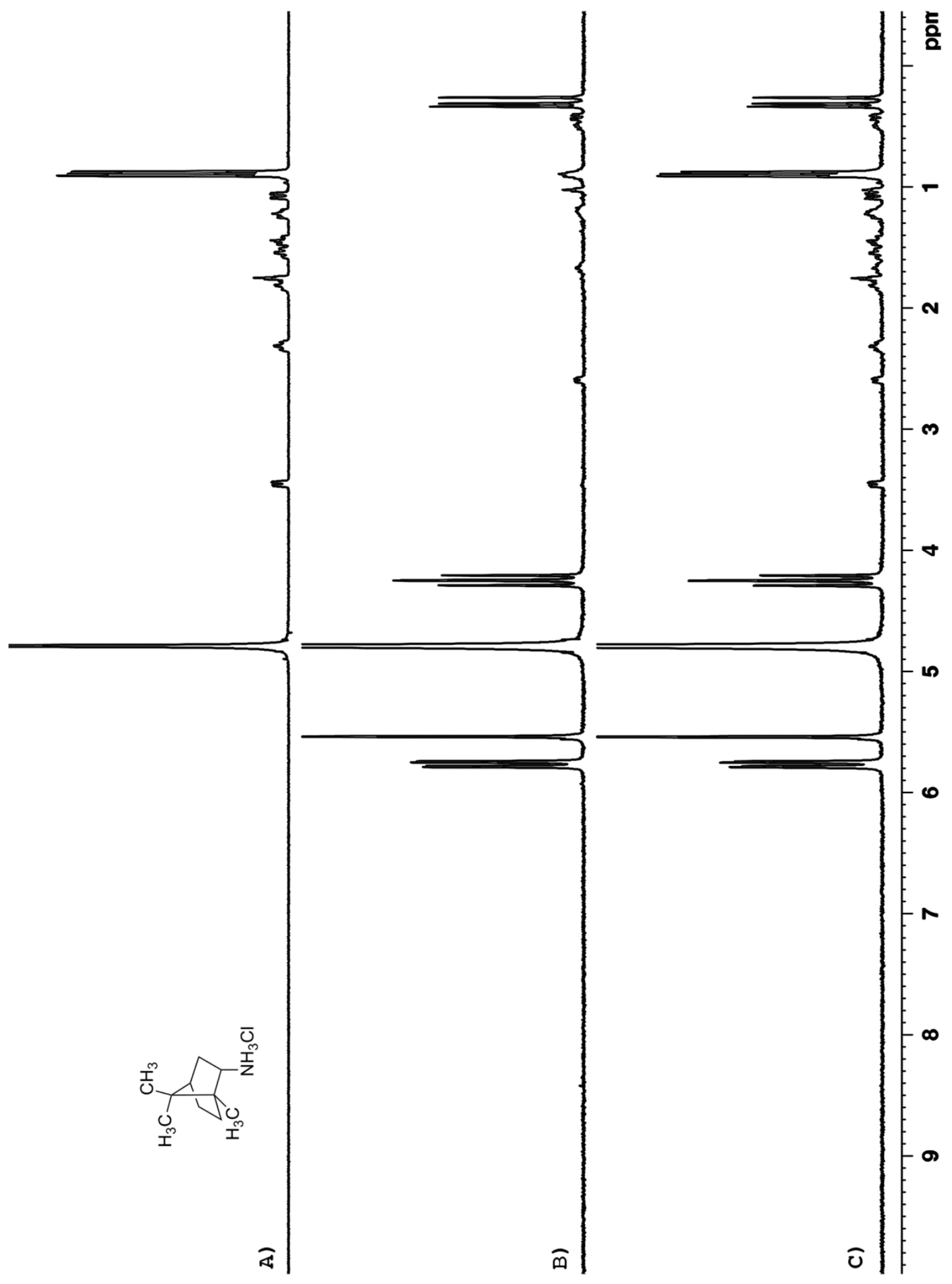

Figure S17. $\quad{ }^{1} \mathrm{H}$ NMR spectra recorded $\left(\mathrm{D}_{2} \mathrm{O}, 400 \mathrm{MHz}, \mathrm{RT}\right)$ for: a) $18(0.25 \mathrm{mM})$, b) a mixture of $\mathrm{CB}$ [7] $(0.25 \mathrm{mM})$ and $\mathbf{1 8}(0.25 \mathrm{mM})$, and c) a mixture of $\mathrm{CB}$ [7] $(0.25 \mathrm{mM})$ and $\mathbf{1 8}$ $(0.5 \mathrm{mM})$. 


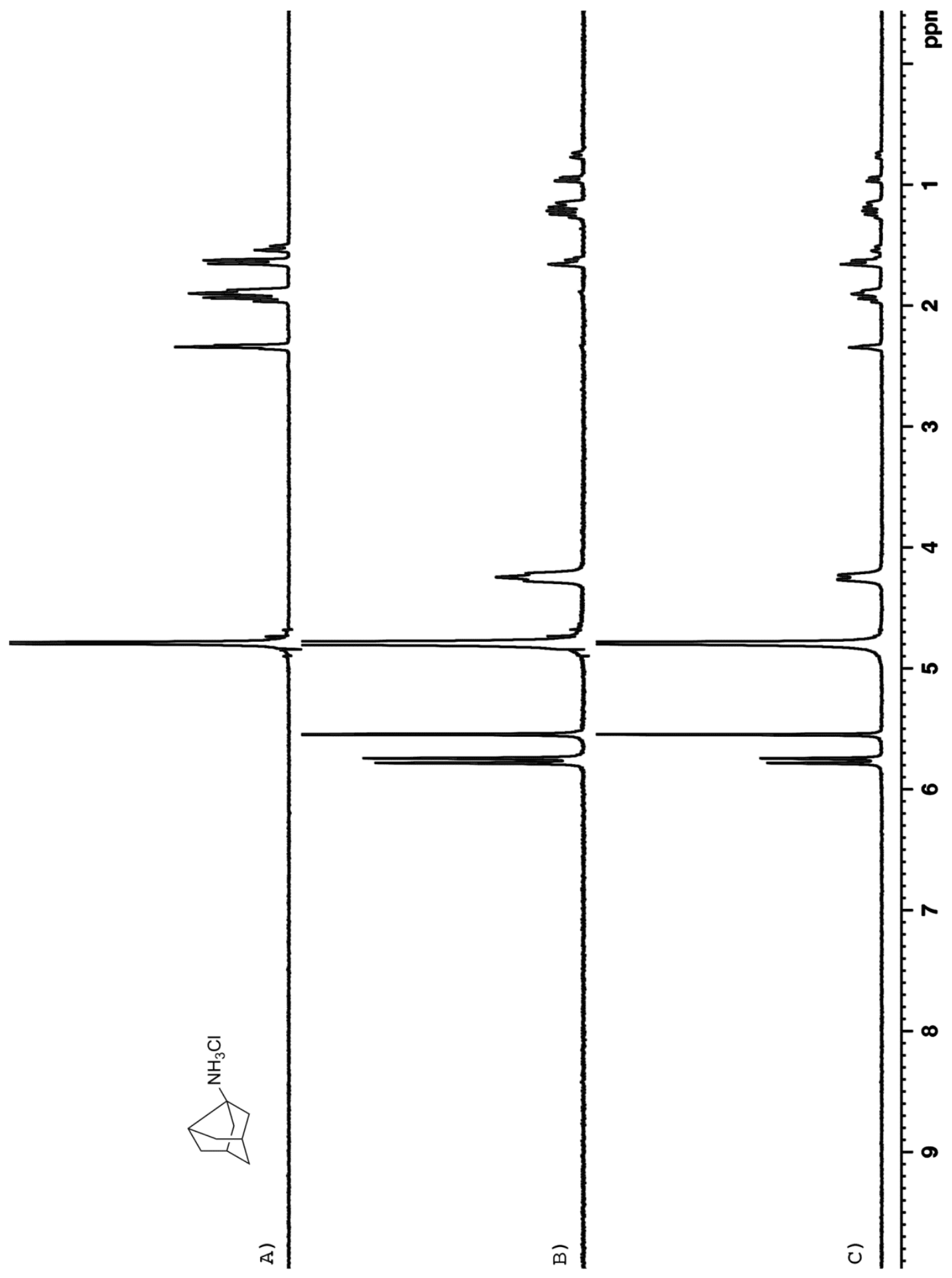

Figure S18. $\quad{ }^{1} \mathrm{H}$ NMR spectra recorded $\left(\mathrm{D}_{2} \mathrm{O}, 400 \mathrm{MHz}, \mathrm{RT}\right)$ for: a) $19(0.25 \mathrm{mM})$, b) a mixture of $\mathrm{CB}$ [7] $(0.25 \mathrm{mM})$ and $19(0.25 \mathrm{mM})$, and $\mathrm{c})$ a mixture of $\mathrm{CB}$ [7] $(0.25 \mathrm{mM})$ and 19 $(0.5 \mathrm{mM})$. 


\section{Job plots by NMR experiments}

The stoichiometry of host-guest complex (CB[7] with 9 or 10) was determined by Job's methods. ${ }^{1}$ The molar ratio of $\mathrm{CB}[7]$ and guest $(\mathbf{9}$ or 10) in the resulting solution varied from 0.1 to 0.9 , in which the total concentration of $\mathrm{CB}$ [7] and guest (9 or 10) was kept constant. The chemical shift $(\Delta \delta)$ were multiplied by molar ratio and plotted against molar ratio to obtain the Job plot. The 1:1 nature of the complexes between $\mathrm{CB}[7]$ and guest 12 is determined by NMR titration.

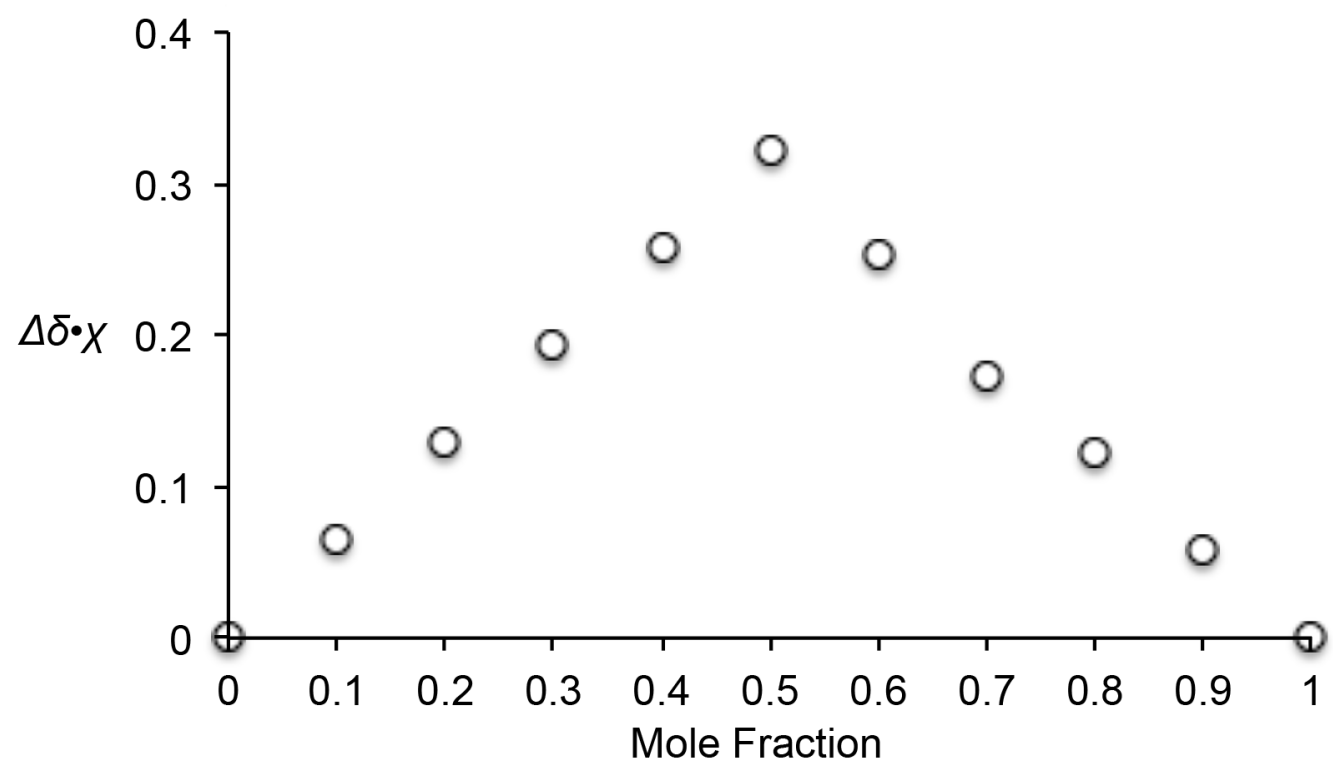

Figure S19. Job plot $\left(\mathrm{D}_{2} \mathrm{O}, 400 \mathrm{MHz}, \mathrm{RT}\right)$ for mixtures of $\mathrm{CB}[7]$ and 9 at a total concentration of $0.5 \mathrm{mM}$. 


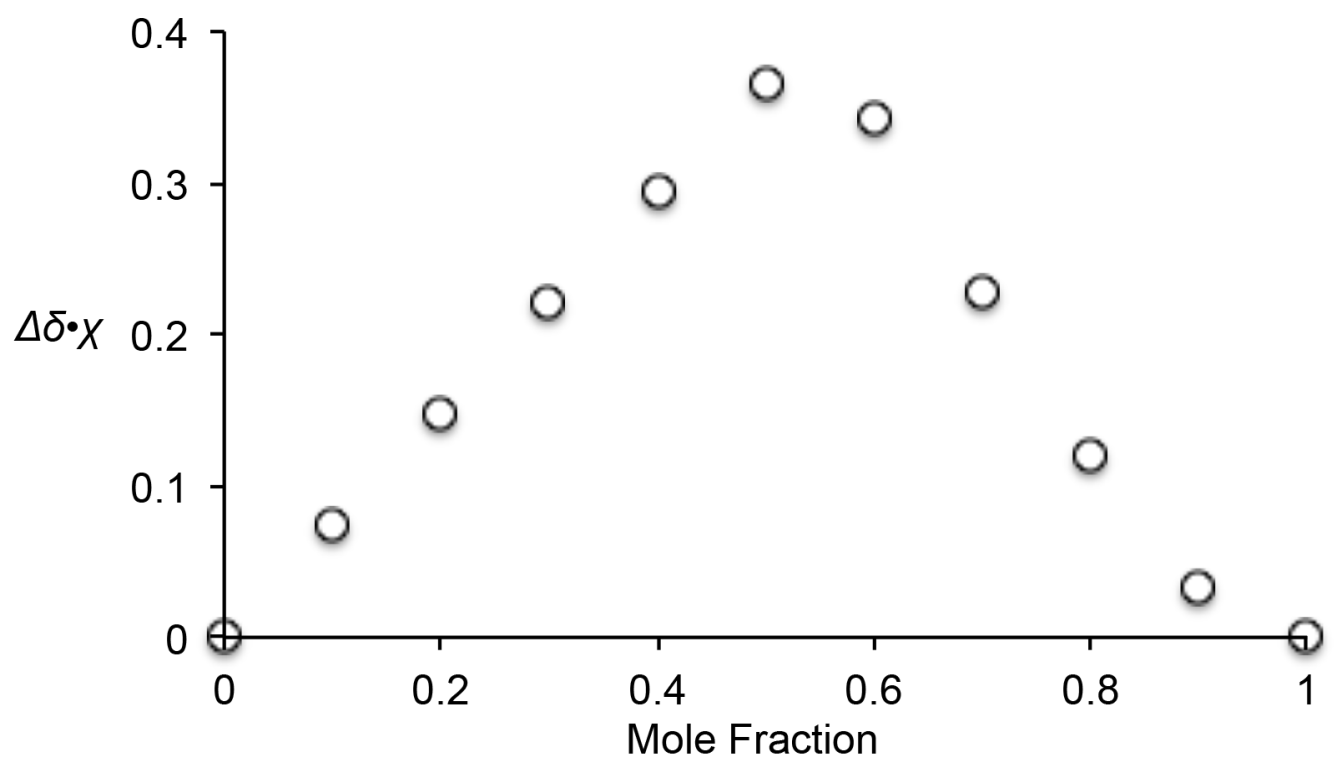

Figure S20. Job plot $\left(\mathrm{D}_{2} \mathrm{O}, 400 \mathrm{MHz}, \mathrm{RT}\right)$ for mixtures of $\mathrm{CB}[7]$ and $\mathbf{1 0}$ at a total concentration of $0.5 \mathrm{mM}$.

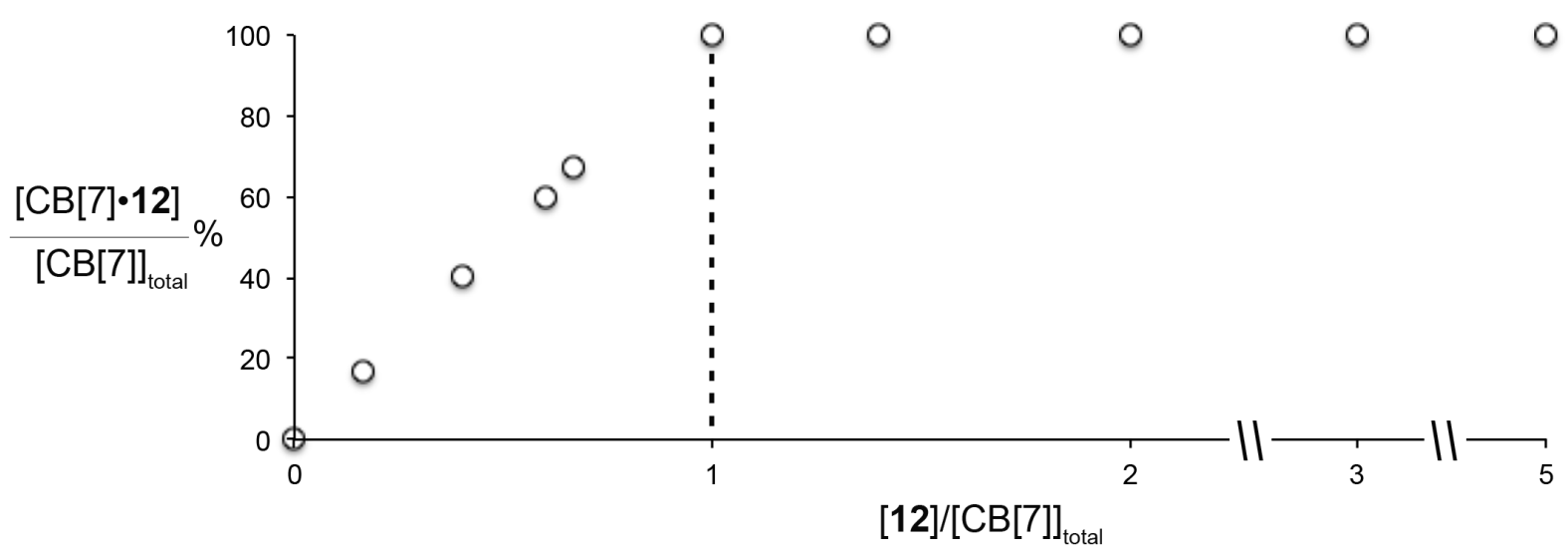

Figure S21. Job plot $\left(\mathrm{D}_{2} \mathrm{O}, 400 \mathrm{MHz}, \mathrm{RT}\right)$ for mixtures of $\mathrm{CB}[7]$ and 12 at a total concentration of $0.5 \mathrm{mM}$. 


\section{Sample Determination of $K_{\text {rel }}$ for the Competition Between 1 and 4 for $C B$ [7]}

We use equation 1 to determine $\mathrm{K}_{\text {rel }}$ for the interaction of $\mathbf{1}$ and $\mathbf{4}$ for $\mathrm{CB}$ [7]. For this purpose, we prepared a solution containing CB[7] $(283.6 \mu \mathrm{M}), \mathbf{1}(2.2502 \mathrm{mM}), \mathbf{4}(325.9 \mu \mathrm{M})$ and allowed it to reach equilibrium (Figure S22). Next, we determined the relative concentration of CB[7]•4 and free 4 by integration of the appropriate resonances in the ${ }^{1} \mathrm{H}$ NMR spectrum (Figure S1.: $\mathrm{CB}[7] \bullet 4: 3.69 \mathrm{ppm}$; free 4: $4.03 \mathrm{ppm})$. Using the concentration and the mass balance expression (equation 2) allowed us to calculat $[4]_{\text {free }}=163.7 \mu \mathrm{M}$ and $[\mathrm{CB}[7] \cdot 4]=162.2 \mu \mathrm{M}$. Equation 3 is then used to calculate $[\mathrm{CB}[7] \bullet \mathbf{1}](121.4 \mu \mathrm{M})$ using the known value of $\mathrm{CB}[7] \bullet 4$. Lastly, equation 4 is used to calculate $[\mathbf{1}]_{\text {free }}(2.1288 \mathrm{mM})$ using the known value of $[\mathrm{CB}[7] \cdot \mathbf{1}]$.

$$
\begin{aligned}
& K_{\text {rel }}=\left([\mathrm{CB}[7] \bullet \mathbf{4}][\mathbf{1}]_{\text {free }}\right) /\left([\mathrm{CB}[7] \cdot \mathbf{1}][\mathbf{4}]_{\text {free }}\right) \\
& {[\mathbf{4}]_{\text {Total }}=325.9 \mu \mathrm{M}=[\mathbf{4}]_{\text {free }}+[\mathrm{CB}[7] \bullet \mathbf{4}]} \\
& {[\mathrm{CB}[7]]_{\text {Total }}=283.6 \mu \mathrm{M}=[\mathrm{CB}[7] \bullet \mathbf{4}]+[\mathrm{CB}[7] \bullet \mathbf{1}]} \\
& {[\mathbf{1}]_{\text {Total }}=2.2502 \mathrm{mM}=[\mathbf{1}]_{\text {free }}+[\mathrm{CB}[7] \bullet \mathbf{1}]}
\end{aligned}
$$

Substitution of the values of $[\mathrm{CB}[7] \bullet \mathbf{1}],[\mathbf{1}]_{\text {free}},[\mathrm{CB}[7] \bullet 4]$, and $[4]_{\text {free }}$ into equation 1 gave $\mathrm{K}_{\text {rel }}=$ 17.4. These determinations were done from independently prepared stock solutions and the average values were used in the calculations of $\mathrm{K}_{\mathrm{a}}$ and the error analysis shown below. In preparing the solutions for the above determinations we used two methods to reach equilibrium: a) A solution of $\mathrm{CB}$ [7] and 1 was prepared, addition of 4 gave the final equilibrium; b) $\mathrm{A}$ solution of $\mathrm{CB}$ [7] and 4 was prepared, addition of 1 gave the final equilibrium. Under those conditions the errors in $[\mathbf{1}]_{\text {free, }}$ are $[\mathbf{4}]_{\text {free }}$ small and both $[\mathrm{CB}[7] \cdot \mathbf{1}]$ and $[\mathrm{CB}[7] \bullet 4)$ are kept in a good range for accurate measurement of their ratio by ${ }^{1} \mathrm{H}$ NMR.

\section{Sample Error Analysis Calculation for CB[7]•19.}

Since the binding constants in this paper are determined by several levels of ${ }^{1} \mathrm{H} N M R$ competition experiments referenced to an absolute $\mathrm{K}_{\mathrm{a}}$ measured for $\mathrm{CB}[7] \bullet \mathbf{1}$ measured by $\mathrm{UV} / \mathrm{V}$ is titration, a proper error analysis is critical. In this section we give a sample calculation of the error analysis used to determine the uncertainty associated with the $\mathrm{K}_{\mathrm{a}}$ value for $\mathrm{CB}[7] \cdot$ 19.

Step 1 - Estimation of the accuracy of ${ }^{1} \mathrm{H}$ NMR methods for the determination of guest and host $\bullet$ guest concentrations. We used ${ }^{1} \mathrm{H}$ NMR to repeatedly determine the concentration of samples of known concentration of guest and host $\bullet$ guest complex by monitoring guest resonances. The ${ }^{1} \mathrm{H}$ NMR based method was accurate with a standard deviation of $\pm 3 \%$ as described previously (Liu, S.; Ruspic, C.; Mukhopadhyay, P.; Chakrabarti, S.; Zavalij, P. Y.; Isaacs, L. J. Am. Chem. Soc. 2005, 127, 15959-15967).

Step 2 - Determination of the Uncertainty Associated with a Single Level of Competition ( $\left.K_{\text {rel }}\right)$. We propagated the above uncertainty associated with the NMR determination of concentrations (e.g. $\left\{\left(\sigma_{[\mathrm{CB}[\mathrm{n}] \cdot \text { guest }]}\right) /[\mathrm{CB}[\mathrm{n}] \cdot\right.$ guest $\left.]\right\}=0.03$ and $\left\{\left(\sigma_{[\text {Guest }]}\right) /[\right.$ Guest $\left.\left.]\right\}=0.03\right)$ of using equations 5 and equations $6-7$ (Bevington, P. R., Robinson, K. D. Data Reduction and Error Analysis for the Physical Sciences, 2nd. ed. McGraw-Hill: New York, 1992, pg. 61-62. eq. 4-11). Equation 6 delivers the uncertainty associated with the weighted product $(\mathrm{x})$ of two values ( $\mathrm{u}$ and $\mathrm{v})$ (e.g. $\mathrm{x}$ $= \pm \mathrm{a} \mathrm{u} \mathrm{v})$. Similarly, equation 7 delivers the uncertainty for dividing two numbers (e.g. $\mathrm{x}= \pm(\mathrm{a}$ 
$\mathrm{u}) / \mathrm{v})$. We make the assumption that the fluctuations in $\mathrm{u}$ and $\mathrm{v}$ are not correlated $\left(\sigma_{\mathrm{uv}}=0\right)$ which when substituted into equations 6 and 7 delivers equation 8 . Rearranging slightly yields equation 9 which allows us to directly use the $3 \%$ uncertainty determined for our NMR method.

$$
\operatorname{Krel}=([\mathrm{CB}[\mathrm{n}] \cdot \mathrm{G} 2][\mathrm{G} 1]) /([\mathrm{CB}[\mathrm{n}] \cdot \mathrm{G} 1][\mathrm{G} 2])
$$

$$
\frac{\sigma_{\mathrm{x}}^{2}}{\mathrm{x}^{2}}=\frac{\sigma_{\mathrm{u}}^{2}}{\mathrm{u}^{2}}+\frac{\sigma_{\mathrm{v}}^{2}}{\mathrm{v}^{2}}+2 \frac{\sigma_{\mathrm{uv}}^{2}}{\mathrm{uv}}
$$

$$
\frac{\sigma_{\mathrm{x}}^{2}}{\mathrm{x}^{2}}=\frac{\sigma_{\mathrm{u}}^{2}}{\mathrm{u}^{2}}+\frac{\sigma_{\mathrm{v}}^{2}}{\mathrm{v}^{2}}-2 \frac{\sigma_{\mathrm{uv}}^{2}}{\mathrm{uv}}
$$

$$
\frac{\sigma_{\mathrm{x}}^{2}}{\mathrm{x}^{2}}=\frac{\sigma_{\mathrm{u}}^{2}}{\mathrm{u}^{2}}+\frac{\sigma_{\mathrm{v}}^{2}}{\mathrm{v}^{2}}
$$

$$
\left(\frac{\sigma_{\mathrm{x}}}{\mathrm{x}}\right)^{2}=\left(\frac{\sigma_{\mathrm{u}}}{\mathrm{u}}\right)^{2}+\left(\frac{\sigma_{\mathrm{v}}}{\mathrm{v}}\right)^{2}
$$

We break the uncertainty determination in $\mathrm{K}_{\text {rel }}$ (equation 1) into three steps: 1) Multiplying $[\mathrm{CB}[\mathrm{n}] \cdot \mathrm{G} 2][\mathrm{G} 1], 2)$ multiplying $[\mathrm{CB}[\mathrm{n}] \cdot \mathrm{G} 1][\mathrm{G} 2]$, and 3) dividing the two results. Substituting $(\sigma[\mathrm{CB}[\mathrm{n}] \cdot \mathrm{G} 2] /[\mathrm{CB}[\mathrm{n}] \cdot \mathrm{G} 2])=0.03$ and $(\sigma[\mathrm{G} 1] /[\mathrm{G} 1])=0.03$ into equation 9 gives equation 10 and an uncertainty of $4.24 \%$ for $[\mathrm{CB}[\mathrm{n}] \cdot \mathrm{G} 2][\mathrm{G} 1]$ (equation 11 ). Similarly, the uncertainty of $[\mathrm{CB}[\mathrm{n}] \cdot \mathrm{G} 1][\mathrm{G} 2]$ is $4.24 \%$.

$$
\left(\frac{\sigma_{[\mathrm{CB}[\mathrm{n}] \cdot \mathrm{G} 2][\mathrm{G} 1]}}{[\mathrm{CB}[\mathrm{n}] \cdot \mathrm{G} 2][\mathrm{G} 1]}\right)^{2}=(0.03)^{2}+(0.03)^{2}
$$

$$
\left(\frac{\sigma_{[\mathrm{CB}[\mathrm{n}] \cdot \mathrm{G} 2][\mathrm{G} 1]}}{[\mathrm{CB}[\mathrm{n}] \cdot \mathrm{G} 2][\mathrm{G} 1]}\right)=0.0424
$$

With the two values of the uncertainties of $[\mathrm{CB}[\mathrm{n}] \cdot \mathrm{G} 2][\mathrm{G} 1]$ and $[\mathrm{CB}[\mathrm{n}] \cdot \mathrm{G} 1][\mathrm{G} 2](4.24 \%)$ in hand we next substituted these values into equation 9 to give the uncertainty in $\mathrm{K}_{\text {rel }}$ (eq. 12-13) of $6 \%$. 


$$
\left(\frac{\sigma_{\mathrm{K}}}{\mathrm{K}_{\mathrm{rel}}}\right)^{2}=\left(\frac{\sigma \frac{[\mathrm{CB}[\mathrm{n}] \cdot \mathrm{G} 2][\mathrm{G} 1]}{[\mathrm{CB}[\mathrm{n}] \cdot \mathrm{G} 2][\mathrm{G} 1]}}{\frac{[\mathrm{CB}[\mathrm{n}] \cdot \mathrm{G} 2][\mathrm{G} 1]}{[\mathrm{CB}[\mathrm{n}] \cdot \mathrm{G} 2][\mathrm{G} 1]}}\right)^{2}=(0.0424)^{2}+(0.0424)^{2}
$$

$$
\frac{\sigma_{\mathrm{K}_{\mathrm{rel}}}}{\mathrm{K}_{\mathrm{rel}}}=0.06
$$

Step 3 - Determination of the Uncertainty in the $\boldsymbol{K}_{\boldsymbol{a}}$ value for $\mathrm{CB}[7] \cdot 1$. We obtained an uncertainty in the value of $\mathrm{K}_{\mathrm{a}}$ for $\mathrm{CB}[7] \cdot \mathbf{1}\left(\mathrm{K}_{\mathrm{a}}=20459 \pm 1168.3 \mathrm{M}^{-1}\right)(5.71 \%)$ from the non-linear least squares fit of the UV/Vis titration data to a 1:1 binding model.

Step 4 - Determination of $K_{a}$ for $\mathrm{CB}[7] \bullet 4$ by competition of 1 and 4 for a limiting quantity of $\boldsymbol{C B}$ [7]. We used ${ }^{1} \mathrm{H}$ NMR competition experiments to determine $\mathrm{K}_{\text {rel }}=7.6$ for these two guests. Substitution of $\mathrm{K}_{\mathrm{CB}[7] \cdot 1}=20459 \pm 1186.3 \mathrm{M}^{-1}$ and $\mathrm{K}_{\text {rel }}$ into equation 14 gave $\mathrm{K}_{\mathrm{CB}[7] \cdot 4}=$ $3.6 \times 10^{5} \mathrm{M}^{-1}$ (equation 15). The uncertainty in $\mathrm{K}_{\mathrm{CB}[7] \cdot 4}$ can be determined using equation 16 . Substituting $\sigma\left(\mathrm{K}_{\mathrm{CB}[7] \cdot 1}\right) / \mathrm{K}_{\mathrm{CB}[7] \cdot 1}=0.05$ and $\sigma\left(\mathrm{K}_{\text {rel }}\right) / \mathrm{K}_{\text {rel }}=0.10$ [Note that we are using the even more conservative $10 \%$ error in this analysis] gives the percent error in $\mathrm{K}_{\mathrm{CB}[7] \cdot 4}$ (equation 17). Substituting eq. 15 into eq. 17 gives $\sigma\left(\mathrm{K}_{\mathrm{CB}[7] \cdot 4}\right)$ (equation 18 ) which can be combined with eq. 15 to give a final value for $\mathrm{K} \mathrm{K}_{\mathrm{CB}[7] \cdot 4}$ (equation 19).

$$
\begin{aligned}
& \mathrm{K}_{\mathrm{CB}[7] \cdot 4}=\left(\mathrm{K}_{\mathrm{CB}[7] \cdot 1}\right)\left(\mathrm{K}_{\mathrm{rel}}\right) \\
& \mathrm{K}_{\mathrm{CB}[7] \cdot 4}=3.6 \times 10^{5} \mathrm{M}^{-1} \\
& \left(\frac{\sigma \mathrm{K}_{\mathrm{CB}[7] \mathrm{g}}}{\mathrm{K}_{\mathrm{CB}[7] \mathrm{g} 4}}\right)^{2}=\left(\frac{\sigma \mathrm{K}_{\mathrm{CB}[7] \mathrm{gl}}}{\mathrm{K}_{\mathrm{CB}[7] \mathrm{gl}}}\right)^{2}+\left(\frac{\sigma \mathrm{K}_{\text {rel }}}{\mathrm{K}_{\text {rel }}}\right)^{2} \\
& \frac{\sigma \mathrm{K}_{\mathrm{CB}[7] \mathrm{g} 4}}{\mathrm{~K}_{\mathrm{CB}[7] \mathrm{g} 4}}=0.1152(11.52 \%) \\
& \sigma \mathrm{K}_{\mathrm{CB}[7] \mathrm{g}^{4}}=(0.1152) \times\left(3.6 \times 10^{5} \mathrm{M}^{-1}\right) \approx 0.4 \times 10^{5} \\
& \mathrm{~K}_{\mathrm{CB}[7] \cdot 4}=(3.6 \pm 0.4) \times 10^{5} \mathrm{M}^{-1}
\end{aligned}
$$

Step 5 - Determination of $K_{a}$ for $\mathrm{CB}[7] \cdot 11$ by competition of 4 and 11 for a limiting quantity of $\boldsymbol{C B}$ [7]. We used ${ }^{1} \mathrm{H}$ NMR competition experiments to determine $\mathrm{K}_{\text {rel }}=2.16 \times 10^{-2}$ for these two guests. Substitution of $\mathrm{K}_{\mathbf{C B}[7] \cdot 4}=(3.6 \pm 0.4) \times 10^{5} \mathrm{M}^{-1}$ and $\mathrm{K}_{\text {rel }}$ into equation 20 gave $\mathrm{K}_{\mathbf{C B}[7] \cdot 11}=1.7 \times 10^{7} \mathrm{M}^{-1}$ (equation 21). The uncertainty in $\mathrm{K}_{\mathbf{C B}[7] \cdot 11}$ can be determined using equation 22. Substituting $\sigma\left(\mathrm{K}_{\mathbf{C B}[7] \cdot 4}\right) / \mathrm{K}_{\mathbf{C B}[7] \cdot 4}=0.1152$ and $\sigma\left(\mathrm{K}_{\mathrm{rel}}\right) / \mathrm{K}_{\text {rel }}=0.10$ [Note that we are using the even more conservative $10 \%$ error in this analysis] gives the percent error in $\mathrm{K}_{\mathbf{C B}[\mathbf{7}] \mathbf{1 1}}$ (equation 23). Substituting eq. 21 into eq. 24 gives $\sigma\left(K_{\mathbf{C B}[7] \cdot 11}\right)$ (equation 24) which can be combined with eq. 21 to give a final value for $\mathrm{K}_{\mathbf{C B}[7] \cdot 12}$ (equation 25).

$\mathrm{K}_{\mathrm{CB}[\mathbf{7}] \cdot 11}=\left(\mathrm{K}_{\mathrm{CB}[\mathrm{7]} \cdot 4}\right)\left(\mathrm{K}_{\mathrm{rel}}\right)$

$\mathrm{K}_{\text {CB[7].11 }}=1.7 \times 10^{7} \mathrm{M}^{-1}$ 


$$
\begin{aligned}
& \left(\frac{\sigma \mathrm{K}_{\mathrm{CB}[7] \mathrm{gl} \mathrm{1}}}{\mathrm{K}_{\mathrm{CB}[7] \mathrm{gl} 1}}\right)^{2}=\left(\frac{\sigma \mathrm{K}_{\mathrm{CB}[7] \mathrm{g} 4}}{\mathrm{~K}_{\mathrm{CB}[7] \mathrm{g} 4}}\right)^{2}+\left(\frac{\sigma \mathrm{K}_{\text {rel }}}{\mathrm{K}_{\text {rel }}}\right)^{2} \\
& \frac{\sigma \mathrm{K}_{\mathrm{CB}[7] \mathrm{g} 1}}{\mathrm{~K}_{\mathrm{CB}[7] \mathrm{gl} 1}}=0.1525(15.25 \%) \\
& \sigma \mathrm{K}_{\mathrm{CB}[7] \mathrm{g} 1}=(0.1525) \times\left(1.7 \times 10^{7} \mathrm{M}^{-1}\right) \approx 0.3 \times 10^{7} \\
& \mathrm{~K}_{\mathrm{CB}[7] \cdot 11}=(1.7 \pm 0.3) \times 10^{7} \mathrm{M}^{-1}
\end{aligned}
$$

Step 6 - Determination of $K_{a}$ for $\mathrm{CB}[7] \cdot 19$ by competition of 11 and 19 for a limiting quantity of $\boldsymbol{C B}$ [7]. We used ${ }^{1} \mathrm{H}$ NMR competition experiments to determine $\mathrm{K}_{\text {rel }}=1248.5$ for these two guests. Substitution of $\mathrm{K}_{\mathbf{C B}[7] \cdot 11}=(1.7 \pm 0.3) \times 10^{7} \mathrm{M}^{-1}$ and $\mathrm{K}_{\text {rel }}$ into equation 26 gave $\mathrm{K}_{\mathbf{C B}[7] \cdot 19}$ $=2.1 \times 10^{10} \mathrm{M}^{-1}$ (equation 27). The uncertainty in $\mathrm{K}_{\mathbf{C B}[7] \cdot 19}$ can be determined using equation 28. Substituting $\sigma\left(\mathrm{K}_{\mathbf{C B}[\text { [7].11 }}\right) / \mathrm{K}_{\mathbf{C B}[\text { [7].11 }}=0.1525$ and $\sigma\left(\mathrm{K}_{\mathrm{rel}}\right) / \mathrm{K}_{\mathrm{rel}}=0.10$ [Note that we are using the even more conservative $10 \%$ error in this analysis] gives the percent error in $\mathrm{K}_{\mathbf{C B} \text { [7].19}}$

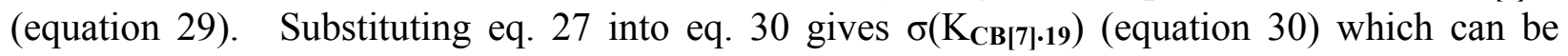
combined with eq. 27 to give a final value for $K_{\mathbf{C B} \text { [7].19 }}$ (equation 31 ).

$$
\begin{aligned}
& \mathrm{K}_{\mathrm{CB}[7] \cdot 19}=\left(\mathrm{K}_{\mathrm{CB}[7] \cdot 11}\right)\left(\mathrm{K}_{\mathrm{rel}}\right) \\
& \mathrm{K}_{\mathrm{CB}[7] \cdot 19}=2.1 \times 10^{10} \mathrm{M}^{-1} \\
& \left(\frac{\sigma \mathrm{K}_{\mathrm{CB}[7] \mathrm{gl} 9}}{\mathrm{~K}_{\mathrm{CB}[7] \mathrm{g} 9}}\right)^{2}=\left(\frac{\sigma \mathrm{K}_{\mathrm{CB}[7] \mathrm{gl} 1}}{\mathrm{~K}_{\mathrm{CB}[7] \mathrm{g} 1}}\right)^{2}+\left(\frac{\sigma \mathrm{K}_{\text {rel }}}{\mathrm{K}_{\text {rel }}}\right)^{2} \\
& \frac{\sigma \mathrm{K}_{\mathrm{CB}[7] \mathrm{g} 9}}{\mathrm{~K}_{\mathrm{CB}[7] \mathrm{g} 19}}=0.1824(18.24 \%) \\
& \sigma \mathrm{K}_{\mathrm{CB}[7] \mathrm{gl} 9}=(0.1824) \times\left(2.1 \times 10^{10} \mathrm{M}^{-1}\right) \approx 0.4 \times 10^{10} \\
& \mathrm{~K}_{\mathrm{CB}[7] \cdot 19}=(2.1 \pm 0.4) \times 10^{10} \mathrm{M}^{-1}
\end{aligned}
$$




\section{Selected ${ }^{1} H$ NMR spectra from the $K_{\mathrm{a}}$ and $K_{\text {rel }}$ measurements}

The following spectra are representative examples of those acquired during the determination of the various $\mathrm{K}_{\mathrm{a}}$ and $\mathrm{K}_{\text {rel }}$ values. The integral is determined by deconvolution of MestRe Nova.

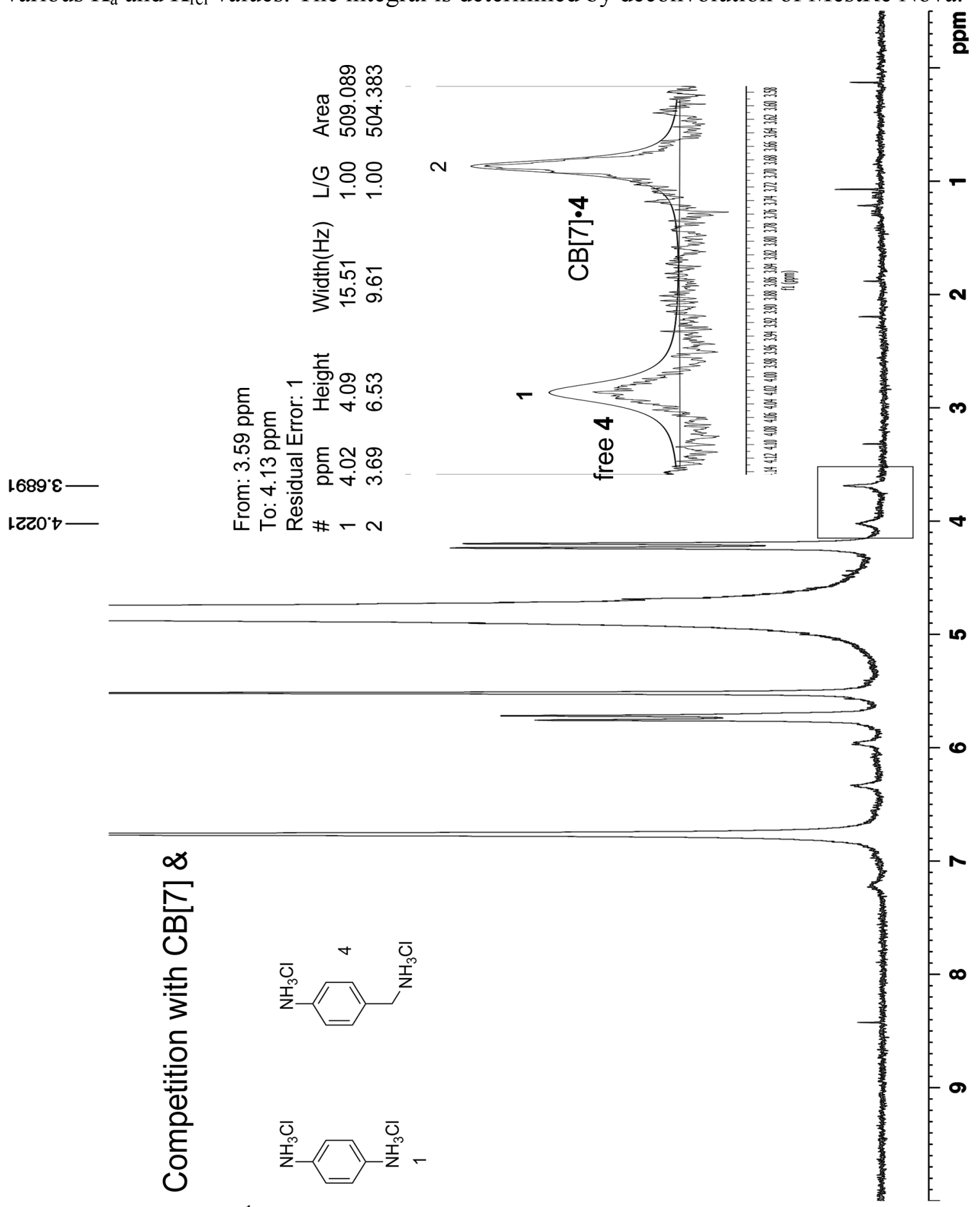

Figure S22. One of the ${ }^{1} \mathrm{H}$ NMR spectra ( $400 \mathrm{MHz}, \mathrm{D}_{2} \mathrm{O}, 100 \mathrm{mM} \mathrm{Na}_{3} \mathrm{PO}_{4}$ buffer, $\mathrm{pH}=7.4$, rt) used in the determination of $\mathrm{K}_{\text {rel }}$ for $\mathrm{CB}[7] \cdot \mathbf{1}$ and $\mathrm{CB}[7] \cdot \mathbf{4}$. [CB[7] $]_{\text {Total }}=0.2836 \mathrm{mM}$, [1] Total $=2.2502 \mathrm{mM},[4]_{\text {Total }}=0.3259 \mathrm{mM}$. 


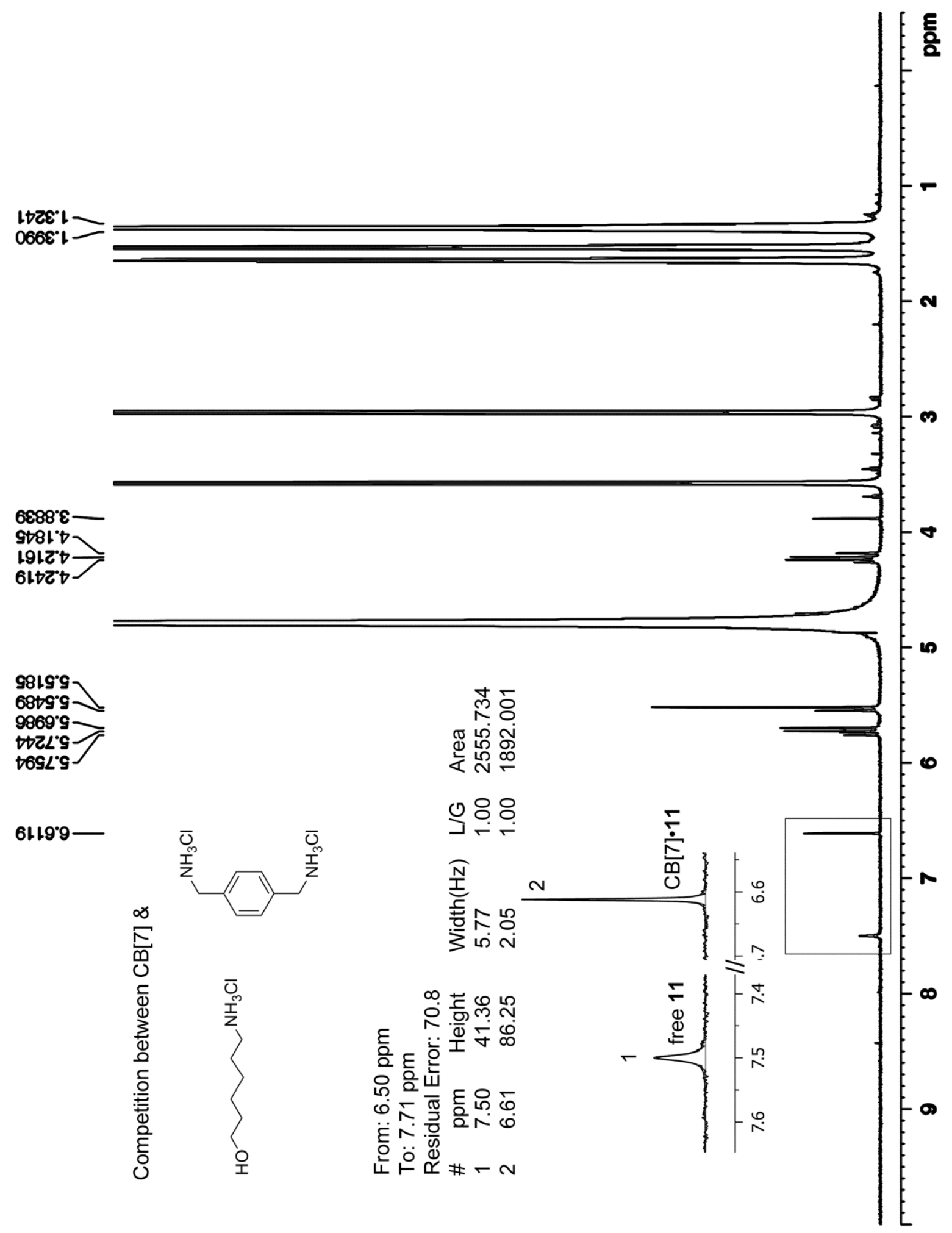

Figure S23. One of the ${ }^{1} \mathrm{H}$ NMR spectra $\left(600 \mathrm{MHz}, \mathrm{D}_{2} \mathrm{O}, 100 \mathrm{mM} \mathrm{Na}{ }_{3} \mathrm{PO}_{4}\right.$ buffer, $\mathrm{pH}=7.4$, rt) used in the determination of $\mathrm{K}_{\text {rel }}$ for $\mathrm{CB}[7] \cdot \mathbf{2}$ and $\mathrm{CB}[7] \bullet \mathbf{1 1}$. $[\mathrm{CB}[7]]_{\text {Total }}=0.2567 \mathrm{mM}$, [2] Total $=29.5961 \mathrm{mM},[\mathbf{1 1}]_{\text {Total }}=0.3878 \mathrm{mM}$. 


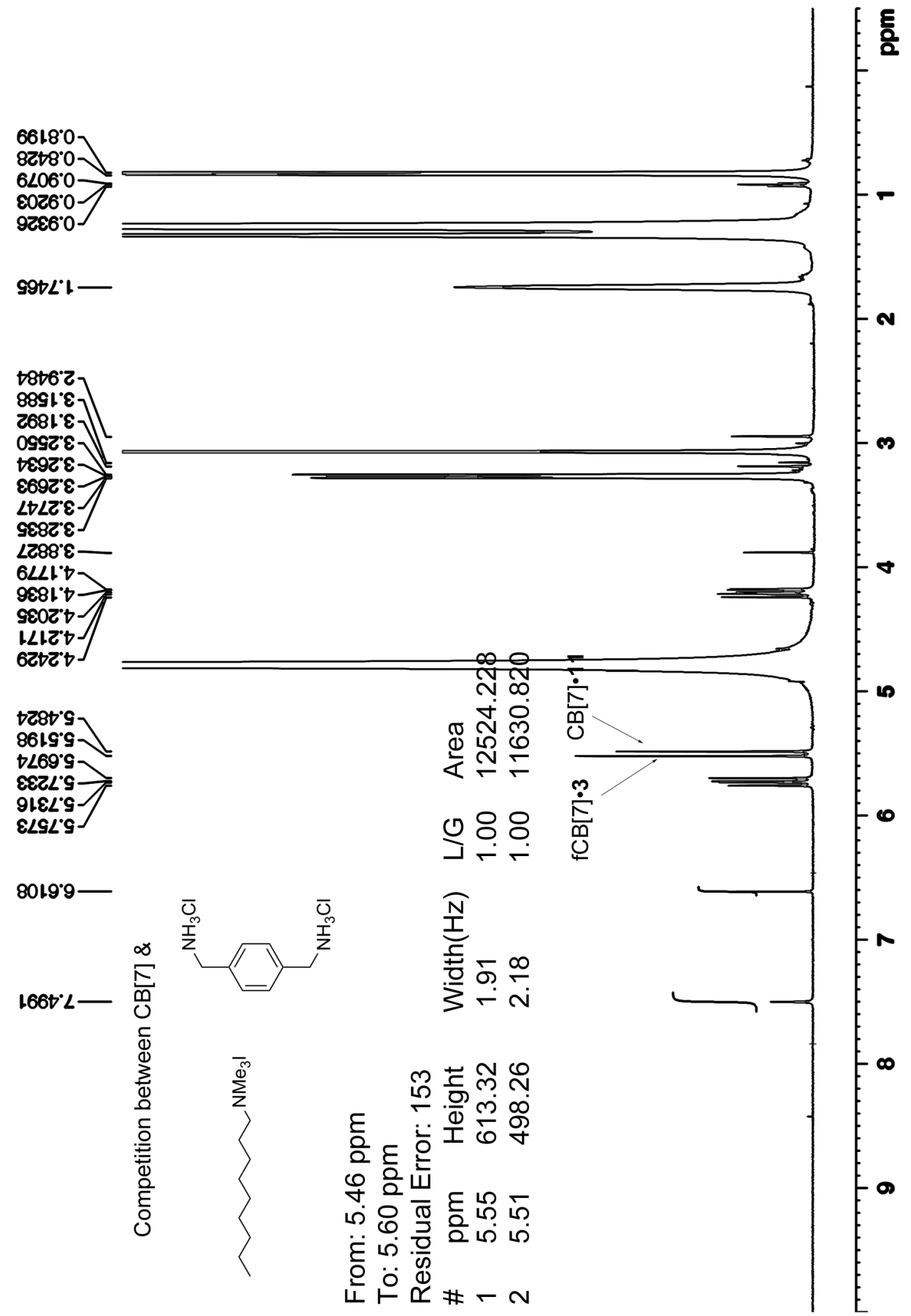

Figure S24. One of the ${ }^{1} \mathrm{H}$ NMR spectra $\left(600 \mathrm{MHz}, \mathrm{D}_{2} \mathrm{O}, 100 \mathrm{mM} \mathrm{Na}_{3} \mathrm{PO}_{4}\right.$ buffer, $\mathrm{pH}=7.4$, $\mathrm{rt}$ ) used in the determination of $\mathrm{K}_{\mathrm{rel}}$ for $\mathrm{CB}[7] \cdot \mathbf{3}$ and $\mathrm{CB}[7] \cdot \mathbf{1 1} .[\mathrm{CB}[7]]_{\text {Total }}=0.2518 \mathrm{mM}$, [3] Total $=12.3796 \mathrm{mM},[\mathbf{1 1}]_{\text {Total }}=0.3878 \mathrm{mM}$. 


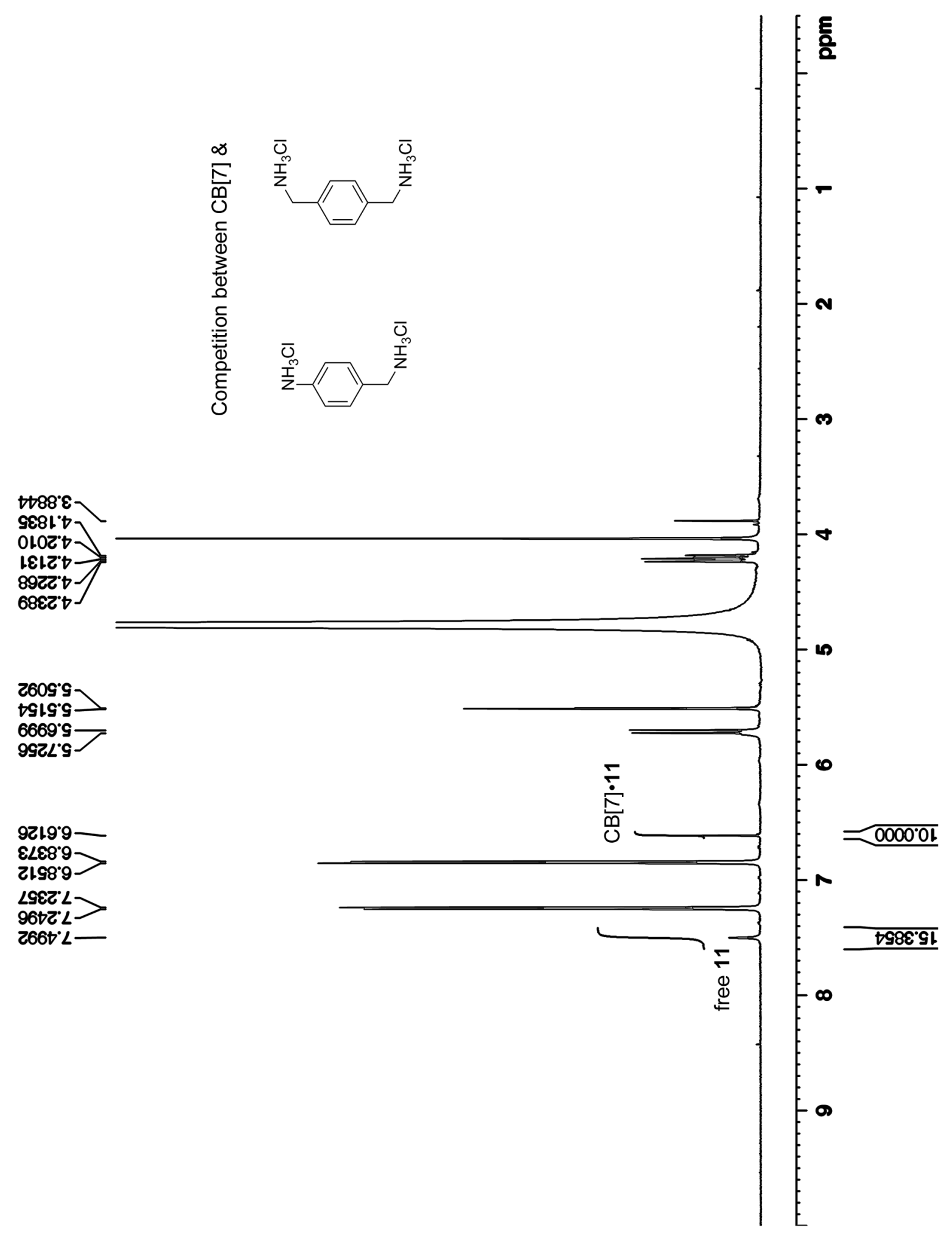

Figure S25. One of the ${ }^{1} \mathrm{H}$ NMR spectra $\left(600 \mathrm{MHz}, \mathrm{D}_{2} \mathrm{O}, 100 \mathrm{mM} \mathrm{Na}{ }_{3} \mathrm{PO}_{4}\right.$ buffer, $\mathrm{pH}=7.4$, rt) used in the determination of $\mathrm{K}_{\text {rel }}$ for $\mathrm{CB}[7] \bullet \mathbf{4}$ and $\mathrm{CB}[7] \bullet \mathbf{1 1}$. $[\mathrm{CB}[7]]_{\text {Total }}=0.2518 \mathrm{mM}$, [4] Total $=4.9216 \mathrm{mM},[\mathbf{1 1}]_{\text {Total }}=0.4654 \mathrm{mM}$. 


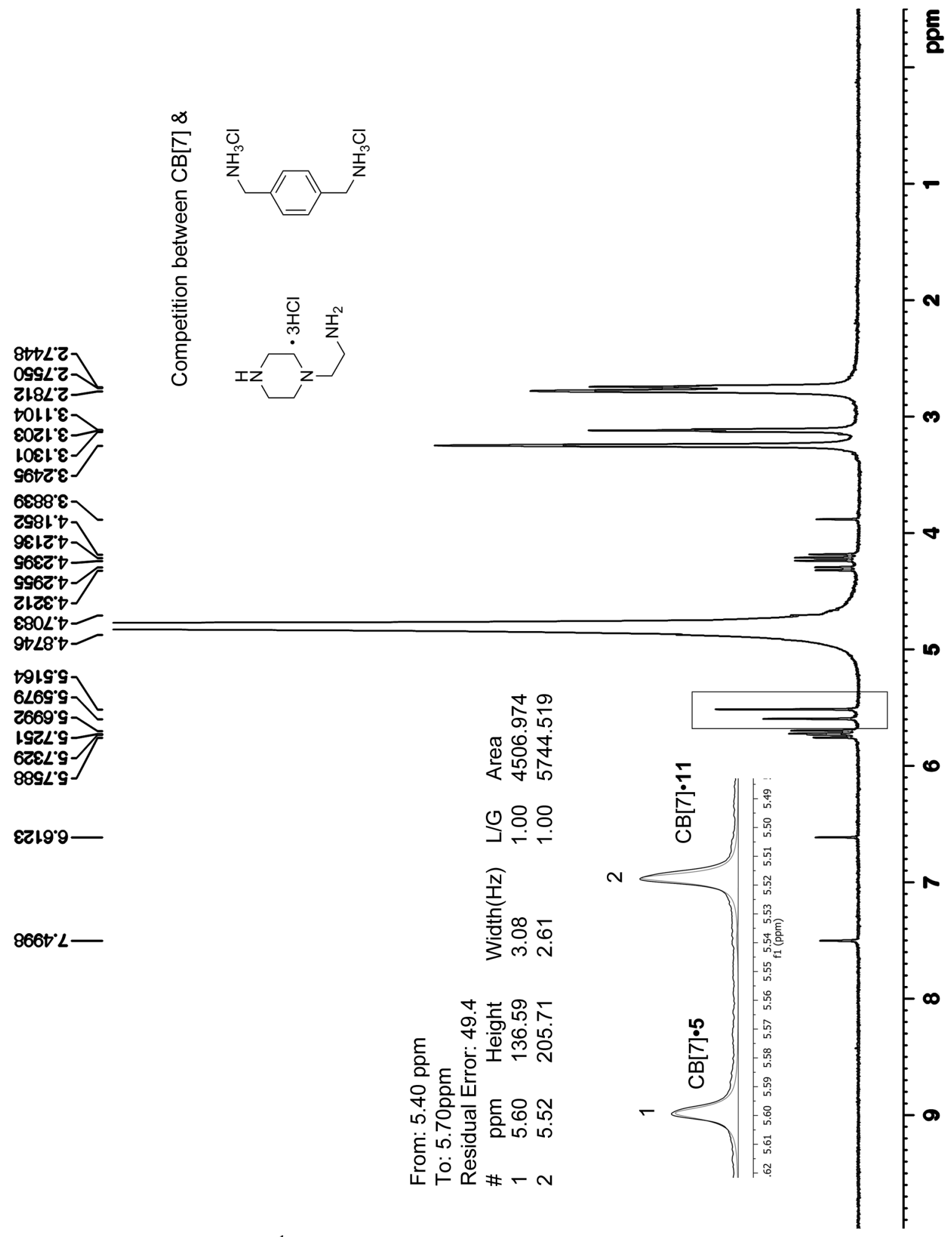

Figure S26. One of the ${ }^{1} \mathrm{H}$ NMR spectra $\left(600 \mathrm{MHz}, \mathrm{D}_{2} \mathrm{O}, 100 \mathrm{mM} \mathrm{Na}_{3} \mathrm{PO}_{4}\right.$ buffer, $\mathrm{pH}=7.4$, $\mathrm{rt}$ ) used in the determination of $\mathrm{K}_{\mathrm{rel}}$ for $\mathrm{CB}[7] \cdot 5$ and $\mathrm{CB}[7] \cdot \mathbf{1 1} .[\mathrm{CB}[7]]_{\text {Total }}=0.2376 \mathrm{mM}$, [5] Total $=5.2846 \mathrm{mM},[\mathbf{1 1}]_{\text {Total }}=0.3591 \mathrm{mM}$. 


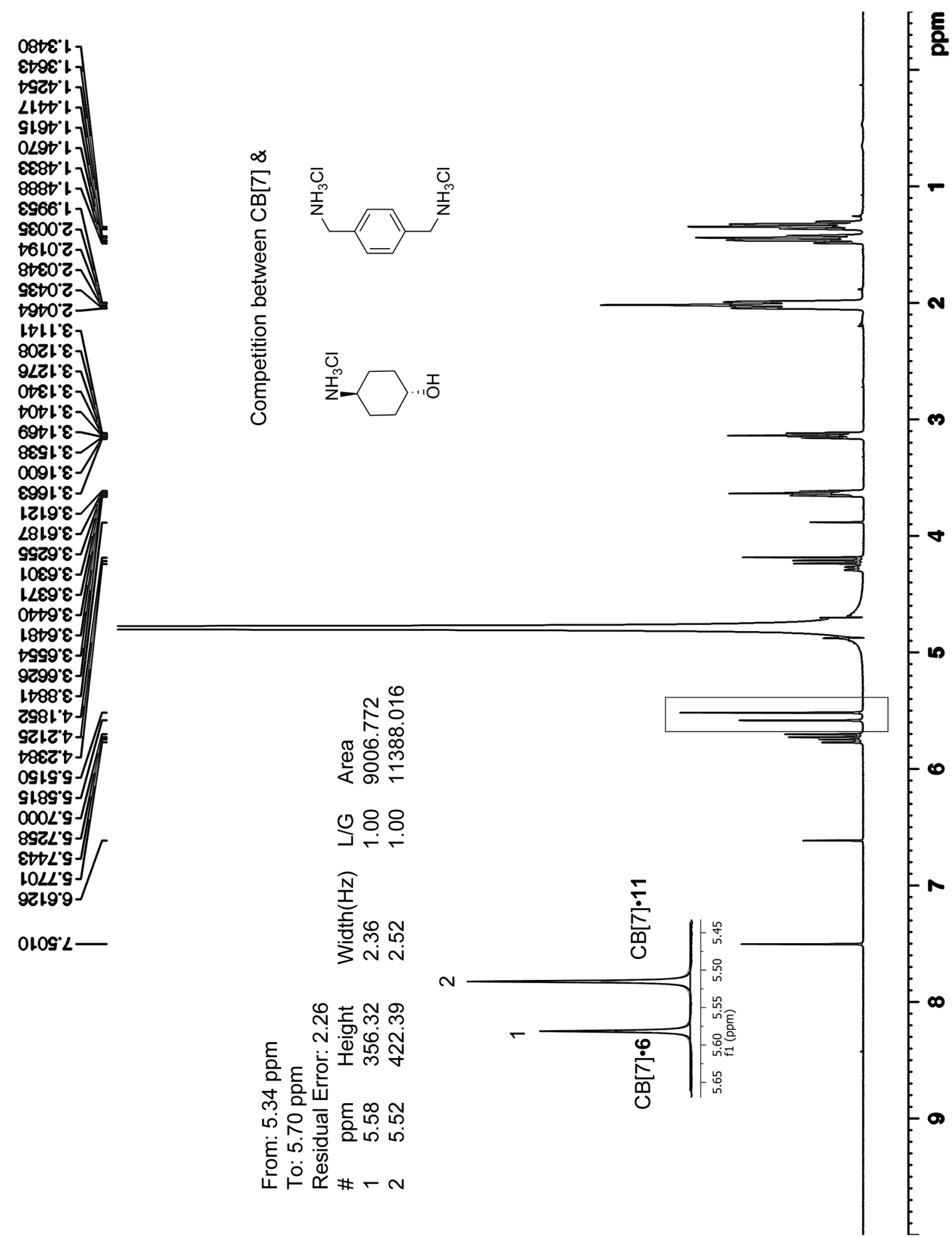

Figure S27. One of the ${ }^{1} \mathrm{H}$ NMR spectra $\left(600 \mathrm{MHz}, \mathrm{D}_{2} \mathrm{O}, 100 \mathrm{mM} \mathrm{Na}_{3} \mathrm{PO}_{4}\right.$ buffer, $\mathrm{pH}=7.4$, $\mathrm{rt}$ ) used in the determination of $\mathrm{K}_{\mathrm{rel}}$ for $\mathrm{CB}[7] \cdot \mathbf{6}$ and $\mathrm{CB}[7] \cdot \mathbf{1 1} .[\mathrm{CB}[7]]_{\text {Total }}=0.2608 \mathrm{mM}$, [6] Total $=7.4173 \mathrm{mM},[\mathbf{1 1}]_{\text {Total }}=0.4985 \mathrm{mM}$. 


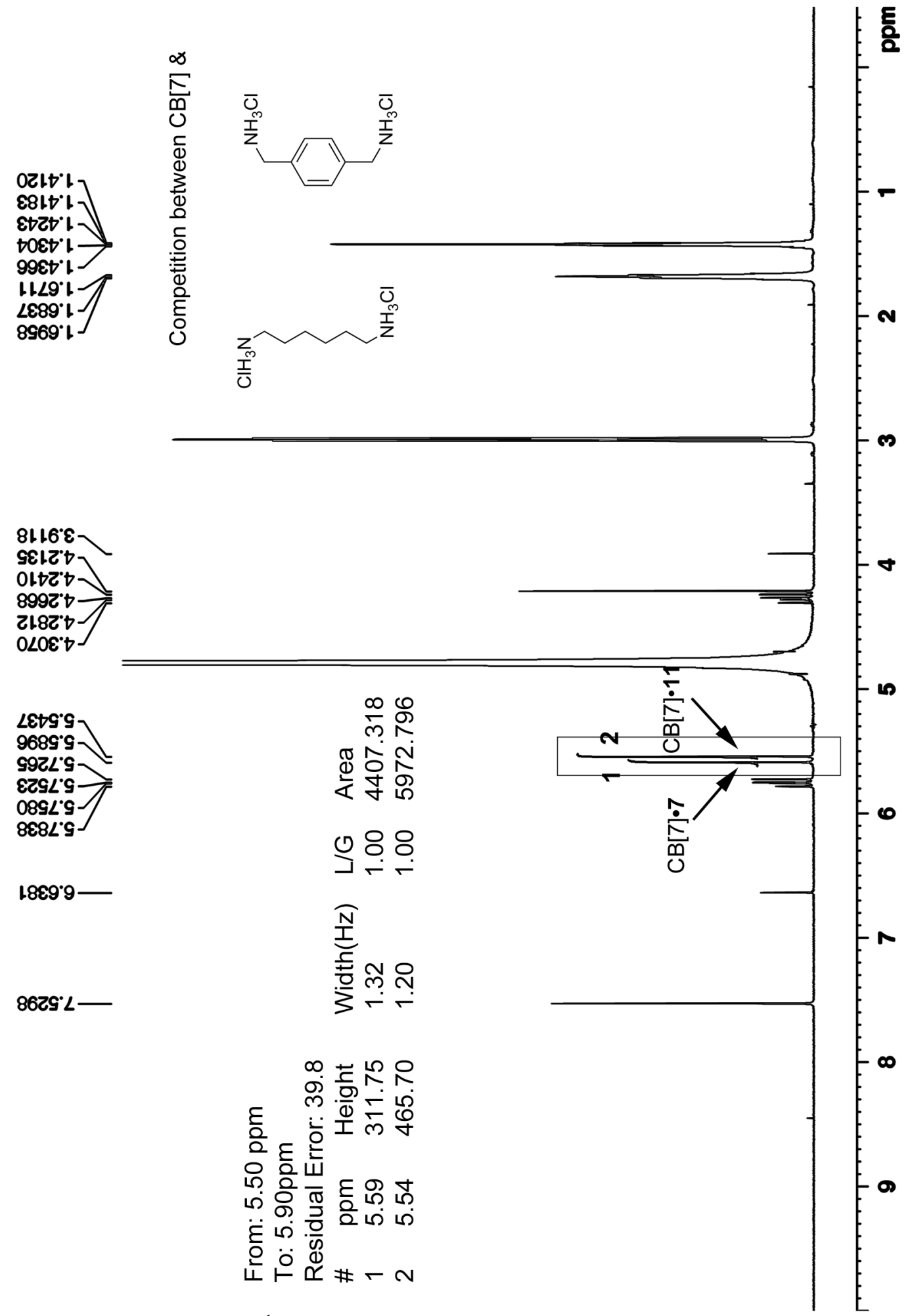

Figure S28. One of the ${ }^{1} \mathrm{H}$ NMR spectra $\left(600 \mathrm{MHz}, \mathrm{D}_{2} \mathrm{O}, 100 \mathrm{mM} \mathrm{Na}_{3} \mathrm{PO}_{4}\right.$ buffer, $\mathrm{pH}=7.4$, rt) used in the determination of $\mathrm{K}_{\text {rel }}$ for $\mathrm{CB}[7] \cdot 7$ and $\mathrm{CB}[7] \bullet 11 .[\mathrm{CB}[7]]_{\text {Total }}=0.2662 \mathrm{mM}$, [7] Total $=8.4185 \mathrm{mM},[\mathbf{1 1}]_{\text {Total }}=1.1406 \mathrm{mM}$. 


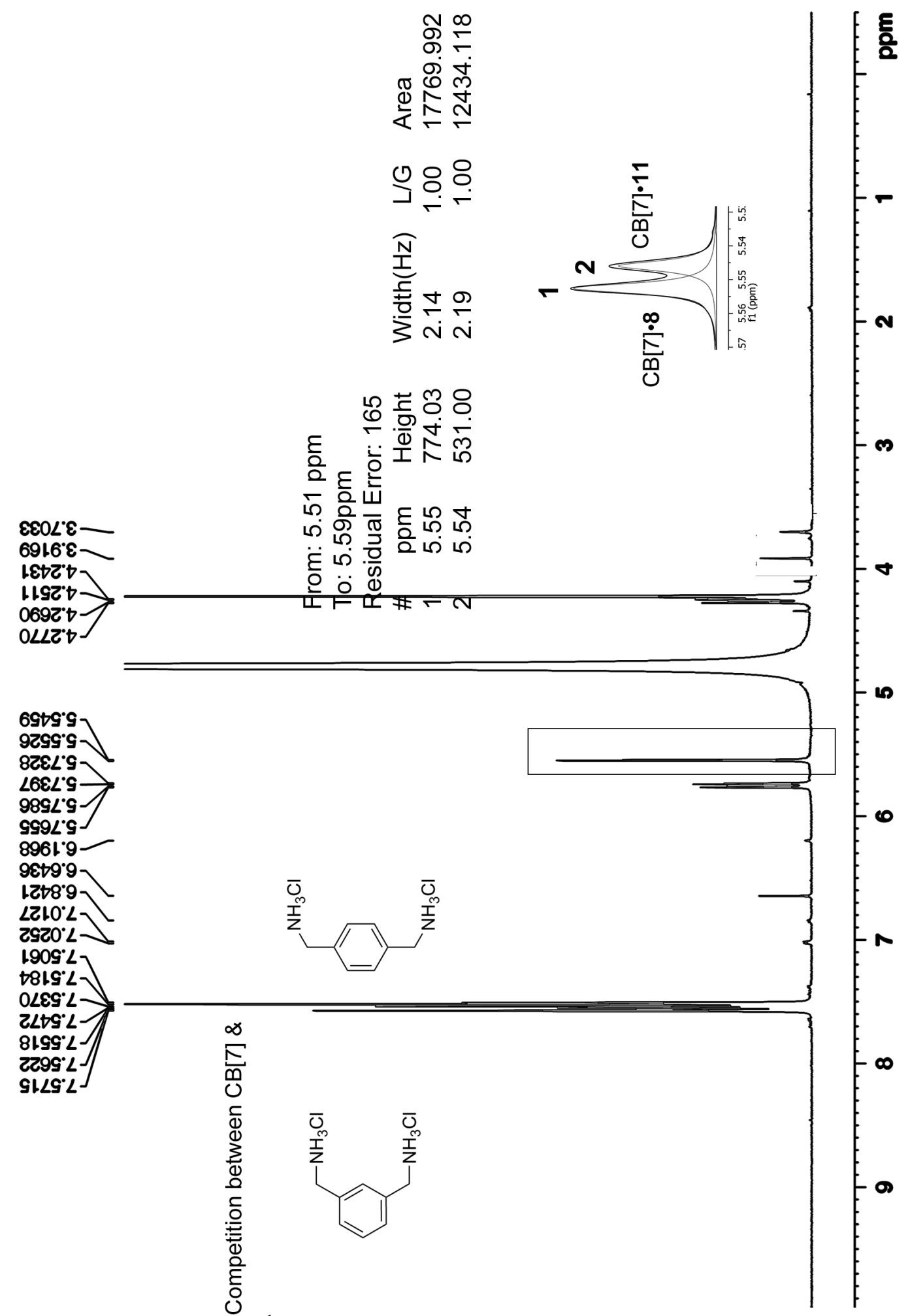

Figure S29. One of the ${ }^{1} \mathrm{H} N \mathrm{NM}$ spectra $\left(600 \mathrm{MHz}, \mathrm{D}_{2} \mathrm{O}, 100 \mathrm{mM} \mathrm{Na}_{3} \mathrm{PO}_{4}\right.$ buffer, $\mathrm{pH}=7.4$, $\mathrm{rt}$ ) used in the determination of $\mathrm{K}_{\mathrm{rel}}$ for $\mathrm{CB}[7] \bullet \mathbf{8}$ and $\mathrm{CB}[7] \bullet \mathbf{1 1} .[\mathrm{CB}[7]]_{\text {Total }}=0.2518 \mathrm{mM}$, $[\mathbf{8}]_{\text {Total }}$ $=5.0873 \mathrm{mM},[11]_{\text {Total }}=0.4654 \mathrm{mM}$. 


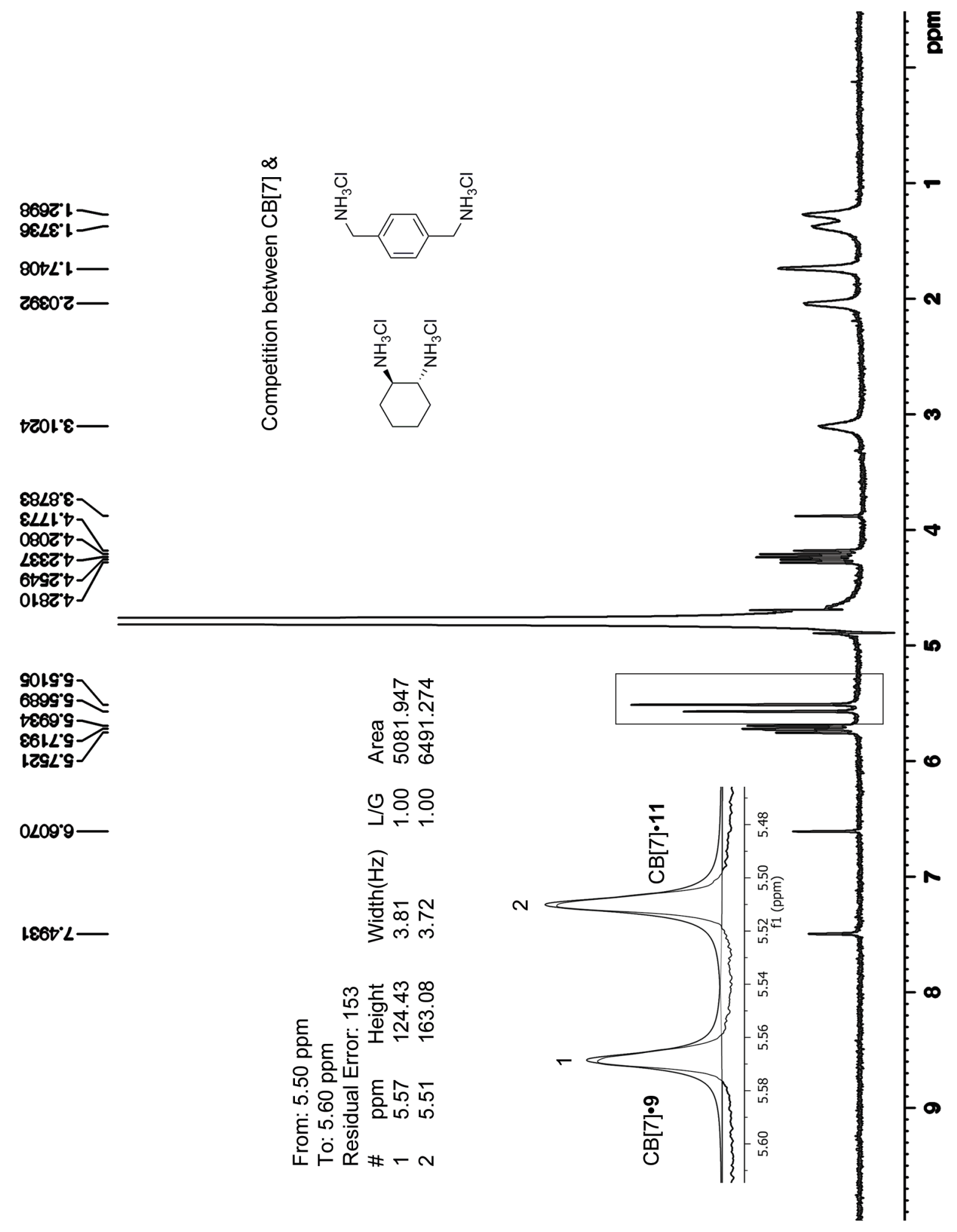

Figure S30. One of the ${ }^{1} \mathrm{H}$ NMR spectra $\left(600 \mathrm{MHz}, \mathrm{D}_{2} \mathrm{O}, 100 \mathrm{mM} \mathrm{Na}_{3} \mathrm{PO}_{4}\right.$ buffer, $\mathrm{pH}=7.4$, rt) used in the determination of $\mathrm{K}_{\text {rel }}$ for $\mathrm{CB}[7] \bullet 9$ and $\mathrm{CB}[7] \bullet \mathbf{1 1}$. [CB[7] $]_{\text {Total }}=0.2567 \mathrm{mM}$, [9] Total $=1.9080 \mathrm{mM},[\mathbf{1 1}]_{\text {Total }}=0.3878 \mathrm{mM}$. 


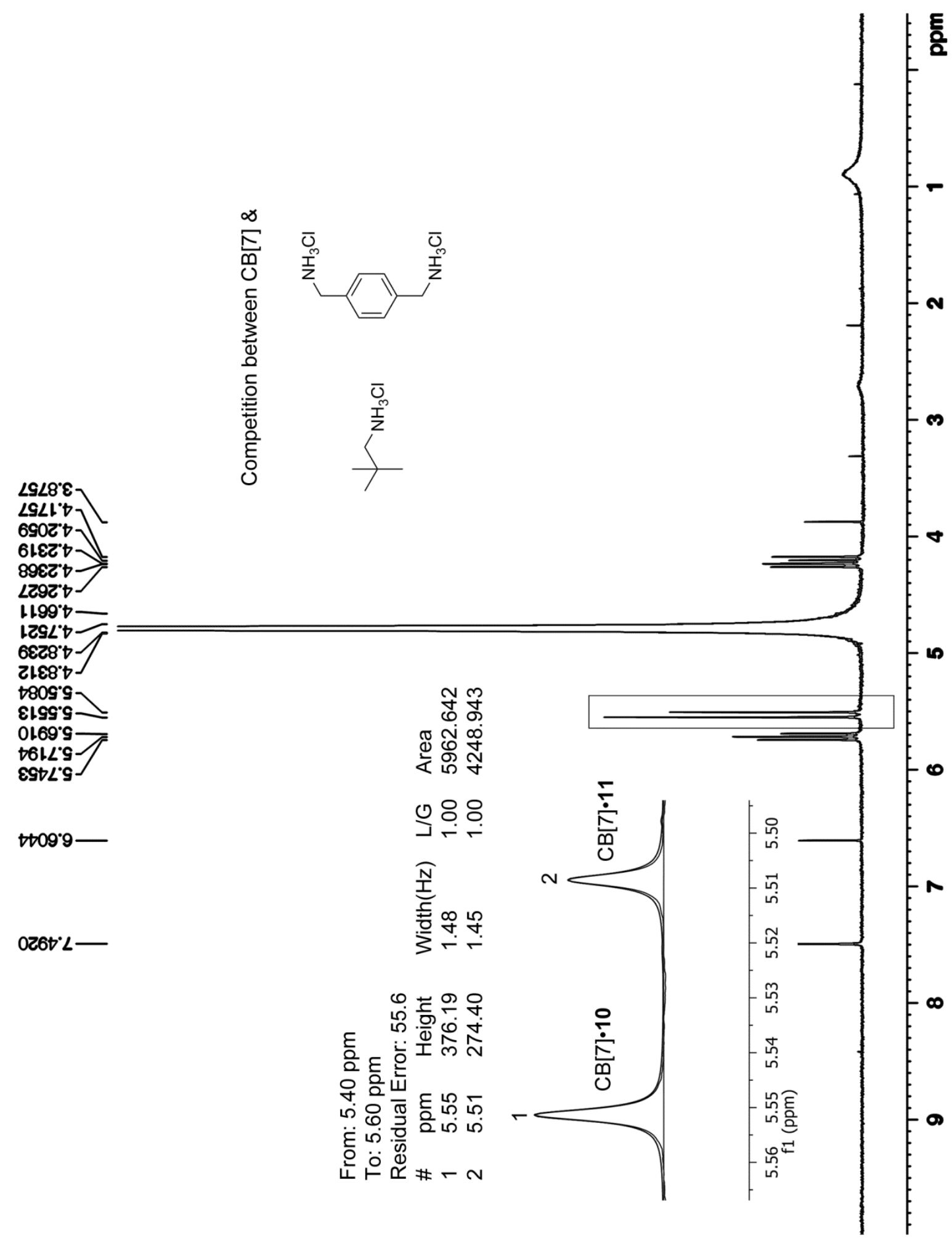

Figure S31. One of the ${ }^{1} \mathrm{H}$ NMR spectra $\left(600 \mathrm{MHz}, \mathrm{D}_{2} \mathrm{O}, 100 \mathrm{mM} \mathrm{Na}_{3} \mathrm{PO}_{4}\right.$ buffer, $\mathrm{pH}=7.4$, $\mathrm{rt}$ ) used in the determination of $\mathrm{K}_{\mathrm{rel}}$ for $\mathrm{CB}[7] \cdot \mathbf{1 0}$ and $\mathrm{CB}[7] \cdot \mathbf{1 1}$. $[\mathrm{CB}[7]]_{\text {Total }}=0.2567 \mathrm{mM}$, [10] Total $=0.7830 \mathrm{mM},[\mathbf{1 1}]_{\text {Total }}=0.3878 \mathrm{mM}$. 


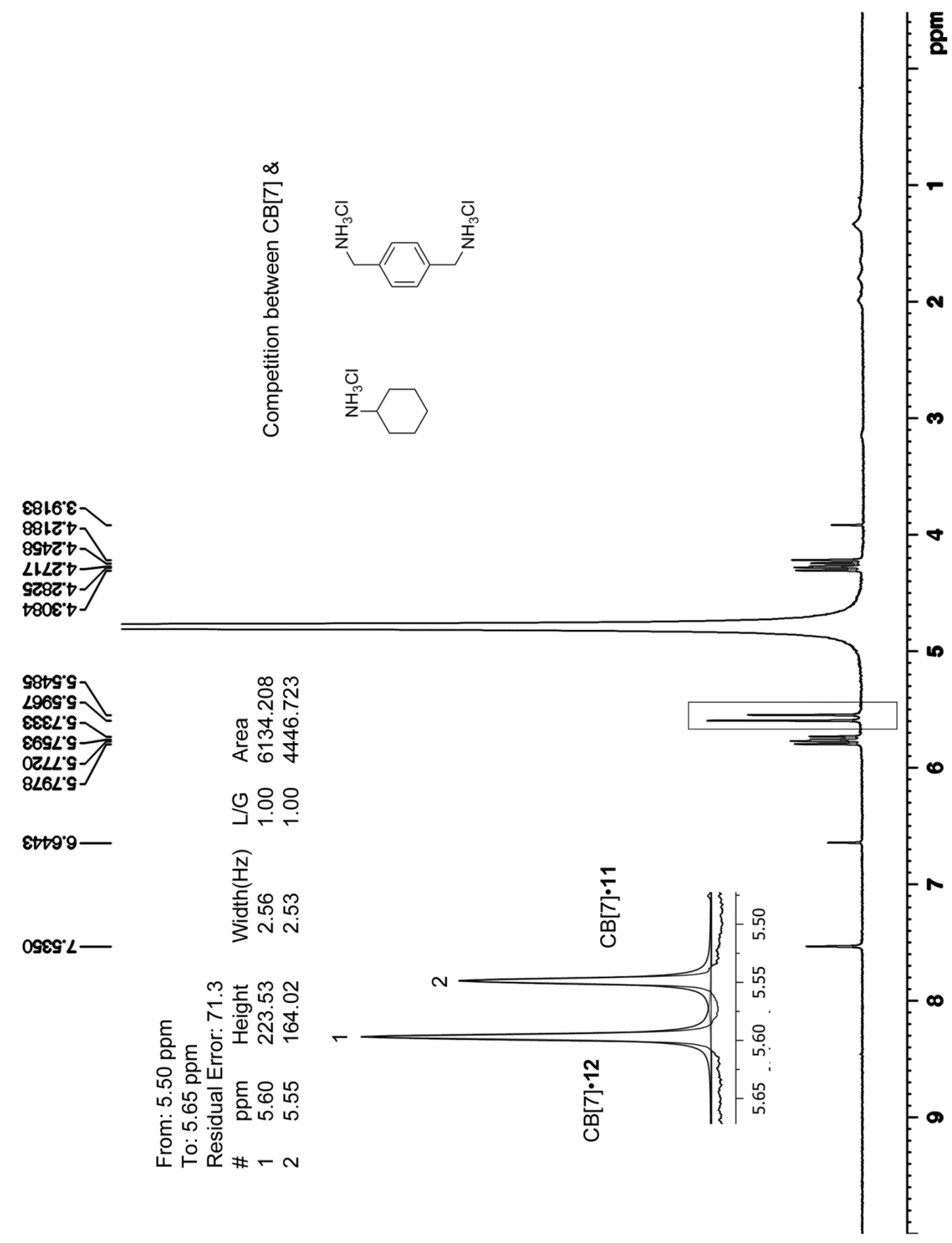

Figure S32. One of the ${ }^{1} \mathrm{H}$ NMR spectra $\left(600 \mathrm{MHz}, \mathrm{D}_{2} \mathrm{O}, 100 \mathrm{mM} \mathrm{Na}{ }_{3} \mathrm{PO}_{4}\right.$ buffer, $\mathrm{pH}=7.4$, rt) used in the determination of $\mathrm{K}_{\text {rel }}$ for $\mathrm{CB}[7] \cdot 12$ and $\mathrm{CB}[7] \bullet \mathbf{1 1}$. [CB[7] $]_{\text {Total }}=0.2715 \mathrm{mM}$, [12] Total $=0.5031 \mathrm{mM},[\mathbf{1 1}]_{\text {Total }}=0.4654 \mathrm{mM}$. 


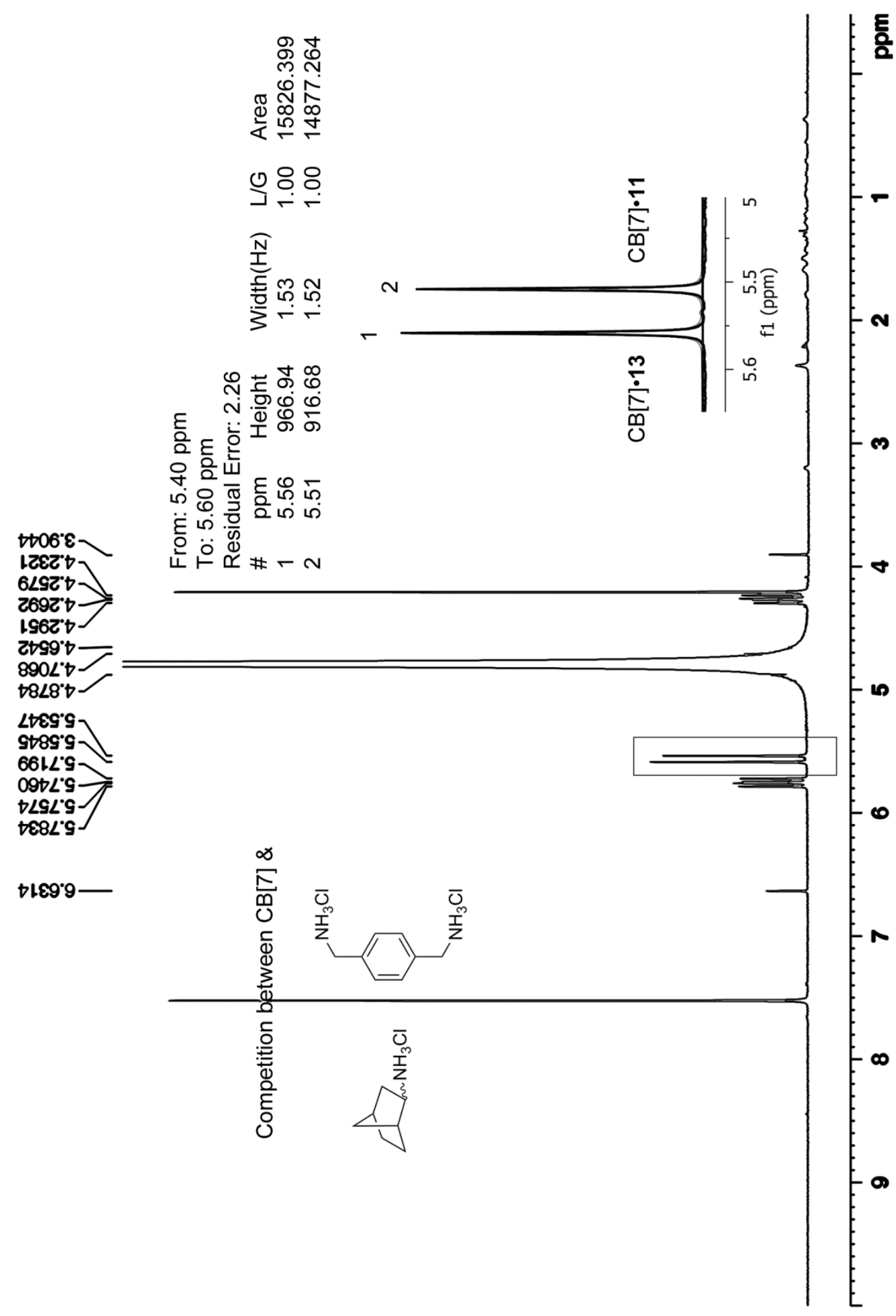

Figure S33. One of the ${ }^{1} \mathrm{H}$ NMR spectra $\left(600 \mathrm{MHz}, \mathrm{D}_{2} \mathrm{O}, 100 \mathrm{mM} \mathrm{Na}_{3} \mathrm{PO}_{4}\right.$ buffer, $\mathrm{pH}=7.4$, $\mathrm{rt})$ used in the determination of $\mathrm{K}_{\mathrm{rel}}$ for $\mathrm{CB}[7] \cdot 13$ and $\mathrm{CB}[7] \cdot \mathbf{1 1}$. [CB[7] $]_{\text {Total }}=0.2608 \mathrm{mM}$, [13] Total $=0.4275 \mathrm{mM},[\mathbf{1 1}]_{\text {Total }}=2.1599 \mathrm{mM}$. 


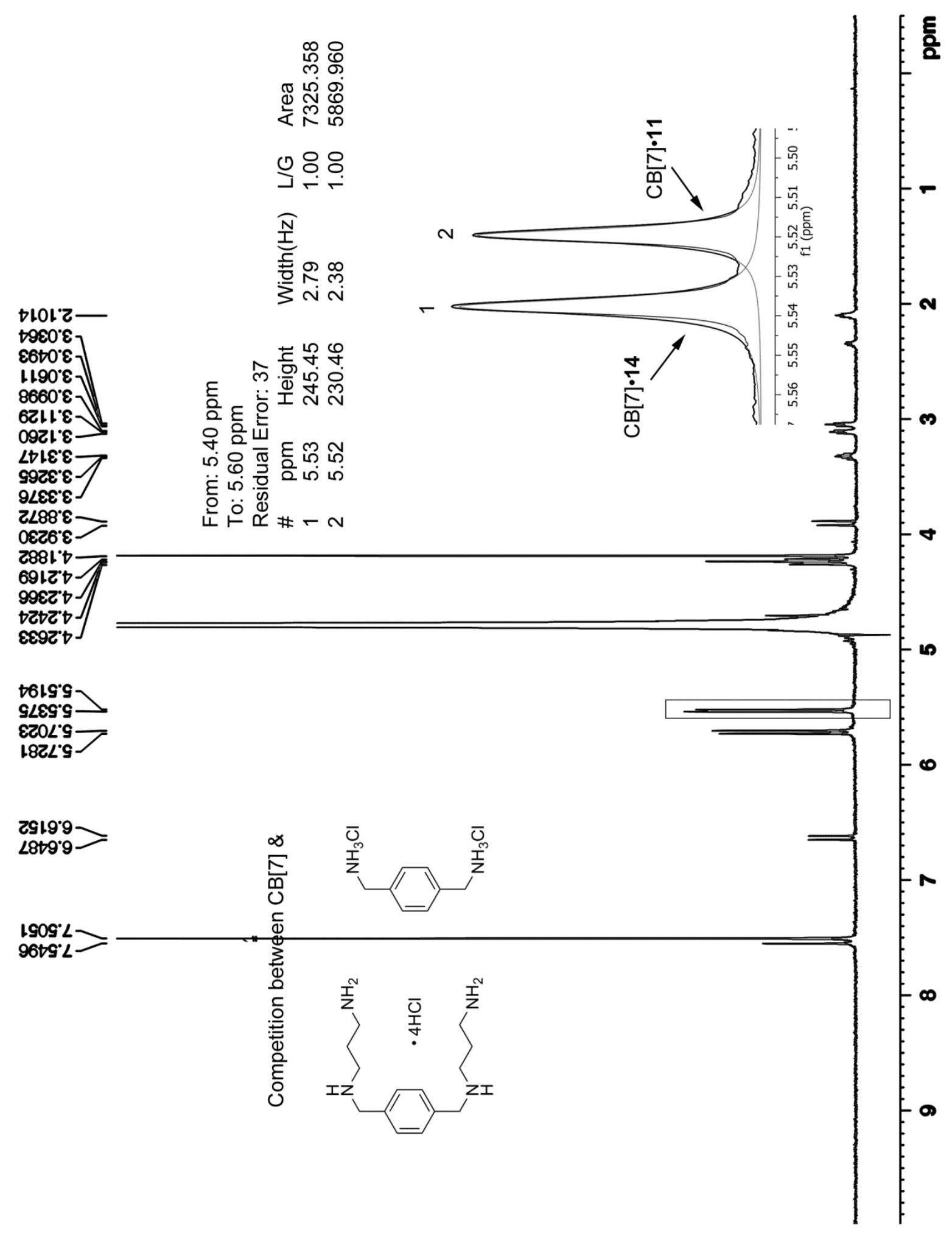

Figure S34. One of the ${ }^{1} \mathrm{H}$ NMR spectra $\left(600 \mathrm{MHz}, \mathrm{D}_{2} \mathrm{O}, 100 \mathrm{mM} \mathrm{Na}_{3} \mathrm{PO}_{4}\right.$ buffer, $\mathrm{pH}=7.4$, $\mathrm{rt}$ ) used in the determination of $\mathrm{K}_{\text {rel }}$ for $\mathrm{CB}[7] \bullet 14$ and $\mathrm{CB}[7] \cdot \mathbf{1 1}$. [CB[7] $]_{\text {Total }}=0.2567 \mathrm{mM}$, [19] Total $=0.4109 \mathrm{mM},[\mathbf{1 1}]_{\text {Total }}=2.3269 \mathrm{mM}$. 


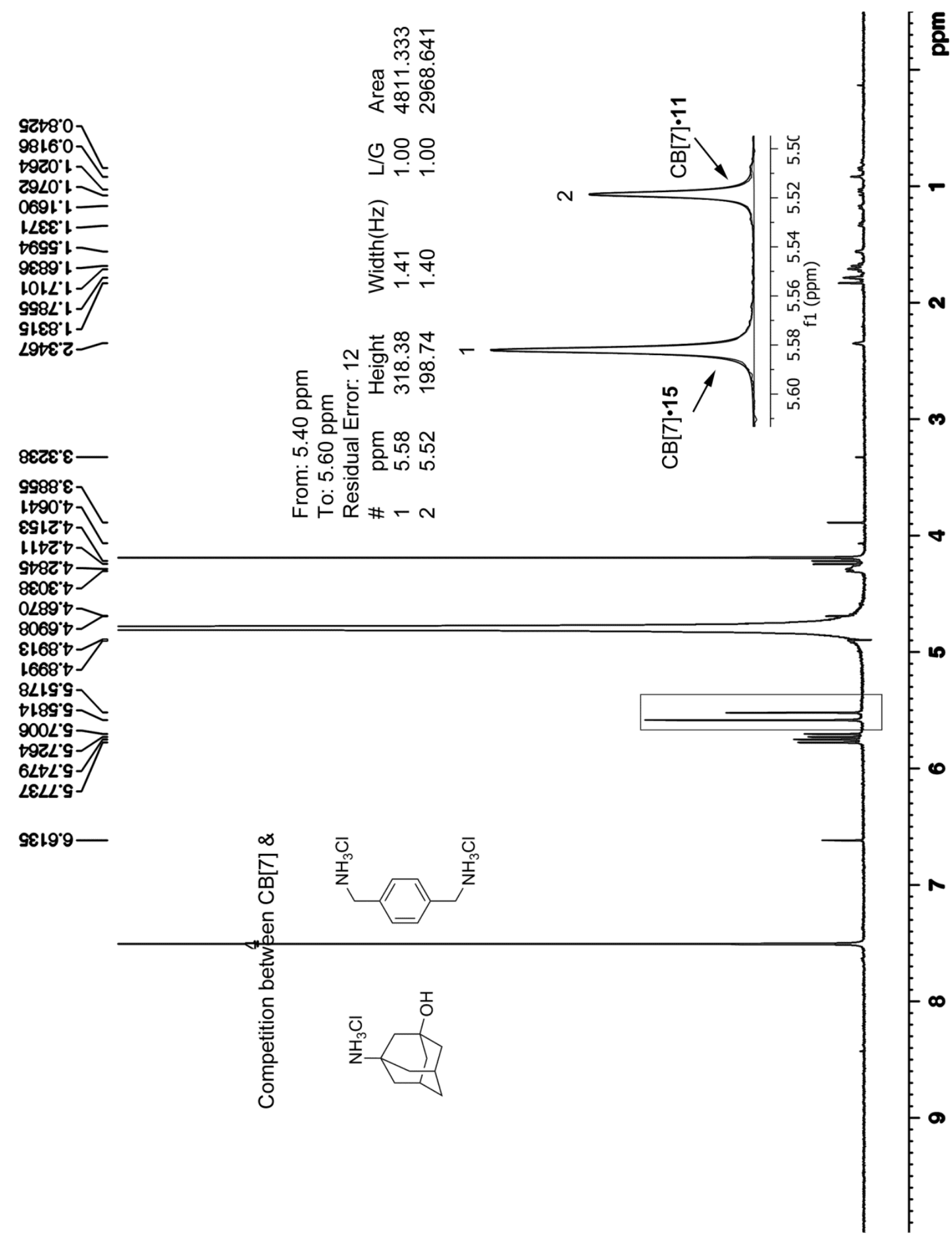

Figure S35. One of the ${ }^{1} \mathrm{H}$ NMR spectra $\left(600 \mathrm{MHz}, \mathrm{D}_{2} \mathrm{O}, 100 \mathrm{mM} \mathrm{Na} \mathrm{PO}_{4}\right.$ buffer, $\mathrm{pH}=7.4$, rt) used in the determination of $\mathrm{K}_{\text {rel }}$ for $\mathrm{CB}[7] \cdot 15$ and $\mathrm{CB}[7] \bullet \mathbf{1 1}$. [CB[7] $]_{\text {Total }}=0.2399 \mathrm{mM}$, [15] Total $=0.3997 \mathrm{mM},[\mathbf{1 1}]_{\text {Total }}=2.8995 \mathrm{mM}$. 


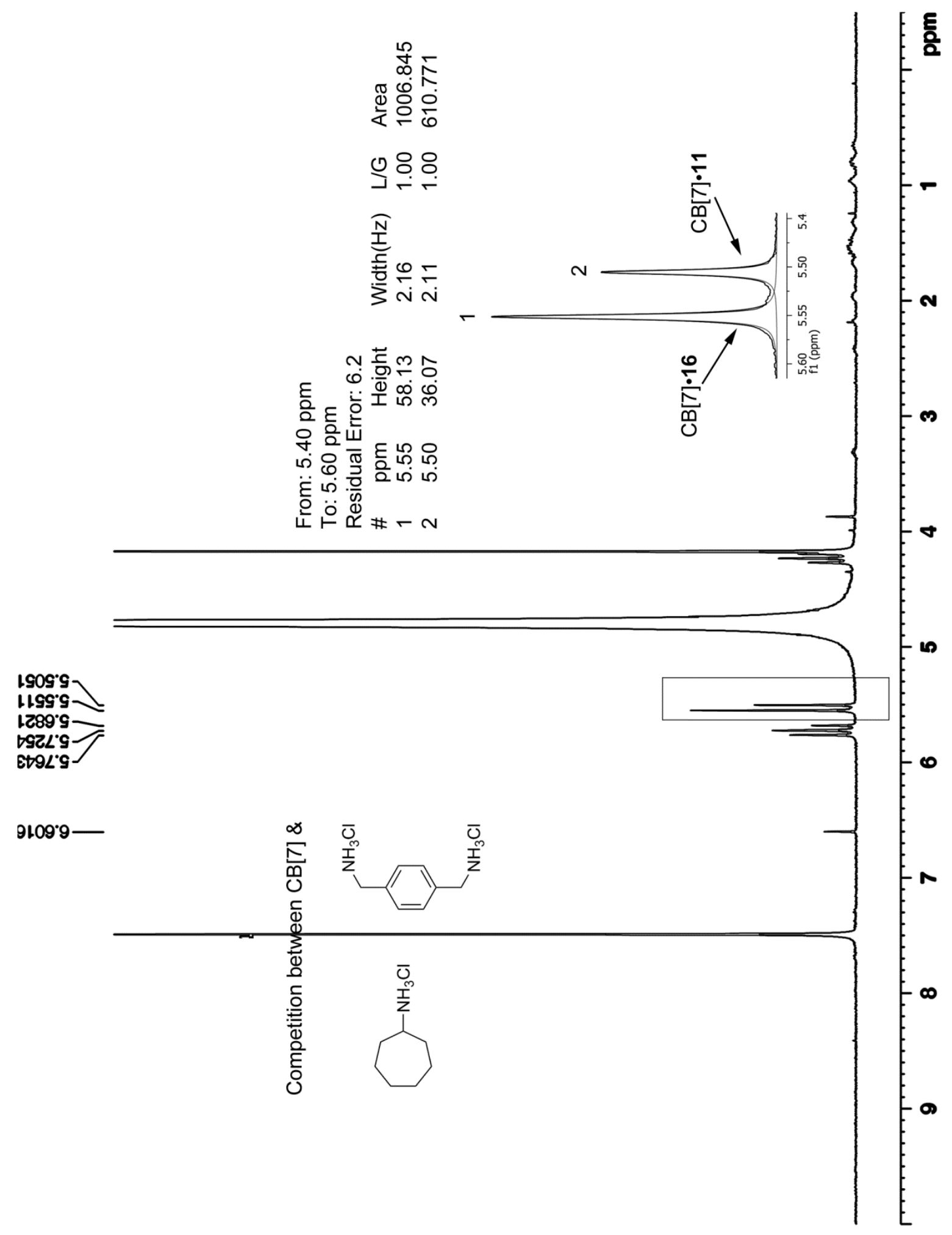

Figure S36. One of the ${ }^{1} \mathrm{H}$ NMR spectra (400 MHz, $\mathrm{D}_{2} \mathrm{O}, 100 \mathrm{mM} \mathrm{Na} \mathrm{PO}_{4}$ buffer, $\mathrm{pH}=7.4$, rt) used in the determination of $\mathrm{K}_{\text {rel }}$ for $\mathrm{CB}[7] \cdot 16$ and $\mathrm{CB}[7] \bullet \mathbf{1 1}$. [CB[7] $]_{\text {Total }}=0.2608 \mathrm{mM}$, [16] Total $=0.4091 \mathrm{mM},[\mathbf{1 1}]_{\text {Total }}=41884 \mathrm{mM}$. 


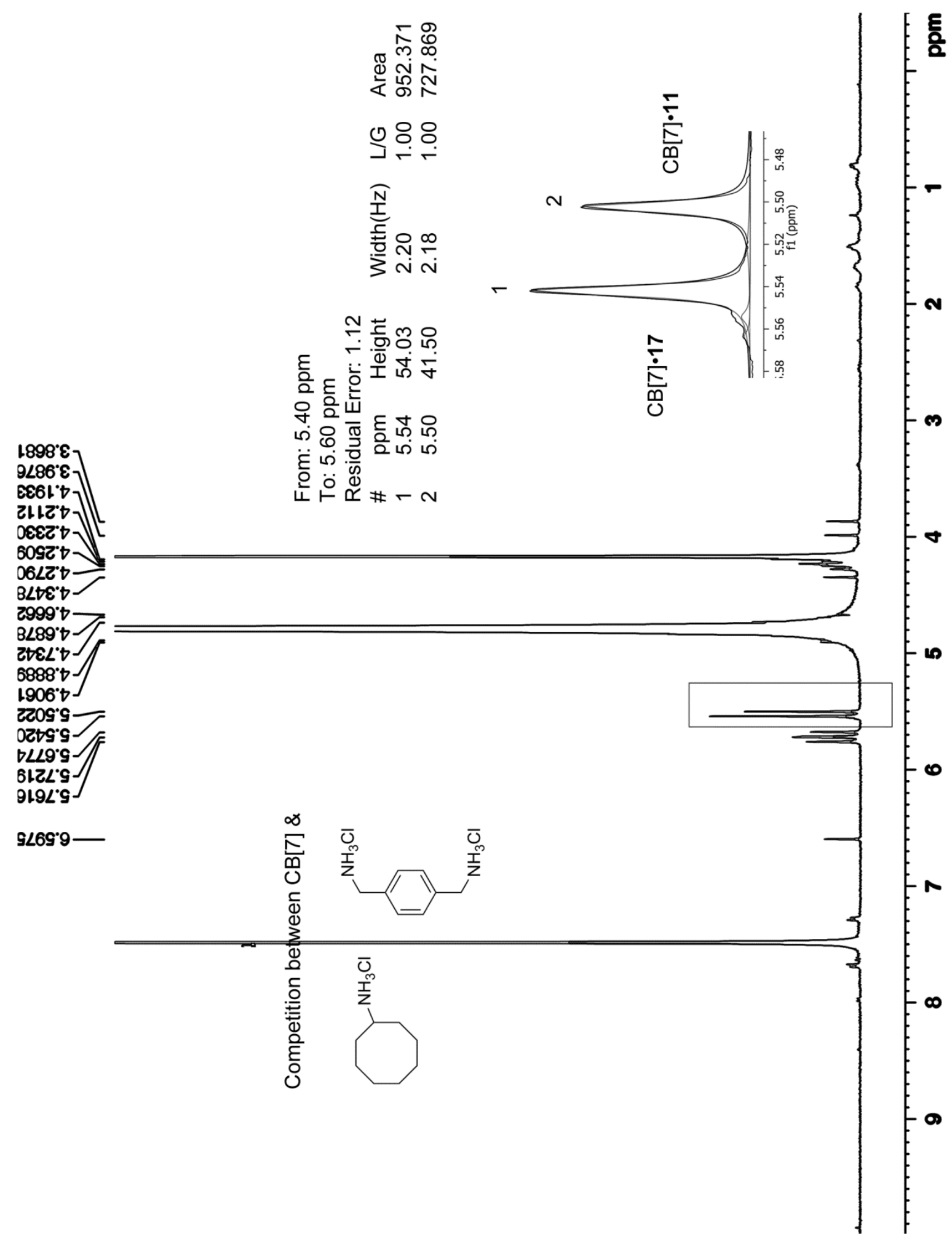

Figure S37. One of the ${ }^{1} \mathrm{H}$ NMR spectra (400 MHz, $\mathrm{D}_{2} \mathrm{O}, 100 \mathrm{mM} \mathrm{Na}_{3} \mathrm{PO}_{4}$ buffer, $\mathrm{pH}=7.4$, rt) used in the determination of $\mathrm{K}_{\mathrm{rel}}$ for $\mathrm{CB}[7] \cdot 17$ and $\mathrm{CB}[7] \cdot \mathbf{1 1}$. $[\mathrm{CB}[7]]_{\text {Total }}=0.2608 \mathrm{mM}$, [17] Total $=0.3985 \mathrm{mM},[\mathbf{1 1}]_{\text {Total }}=19.9415 \mathrm{mM}$. 


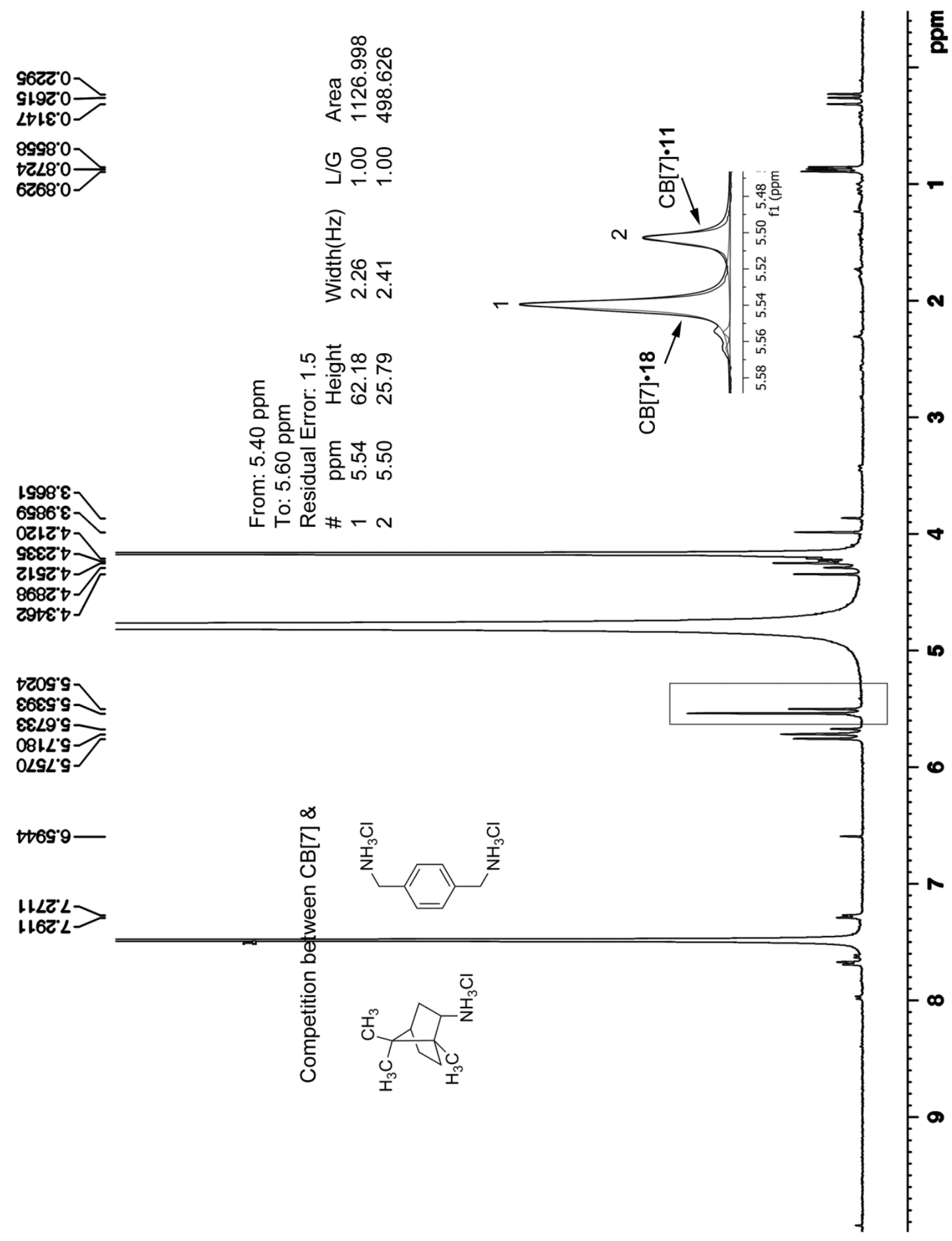

Figure S38. One of the ${ }^{1} \mathrm{H}$ NMR spectra $\left(400 \mathrm{MHz}, \mathrm{D}_{2} \mathrm{O}, 100 \mathrm{mM} \mathrm{Na}_{3} \mathrm{PO}_{4}\right.$ buffer, $\mathrm{pH}=7.4$, rt) used in the determination of $\mathrm{K}_{\text {rel }}$ for $\mathrm{CB}[7] \cdot 18$ and $\mathrm{CB}[7] \bullet \mathbf{1 1}$. [CB[7] $]_{\text {Total }}=0.2608 \mathrm{mM}$, [18] Total $=0.4856 \mathrm{mM},[\mathbf{1 1}]_{\text {Total }}=41.5448 \mathrm{mM}$. 


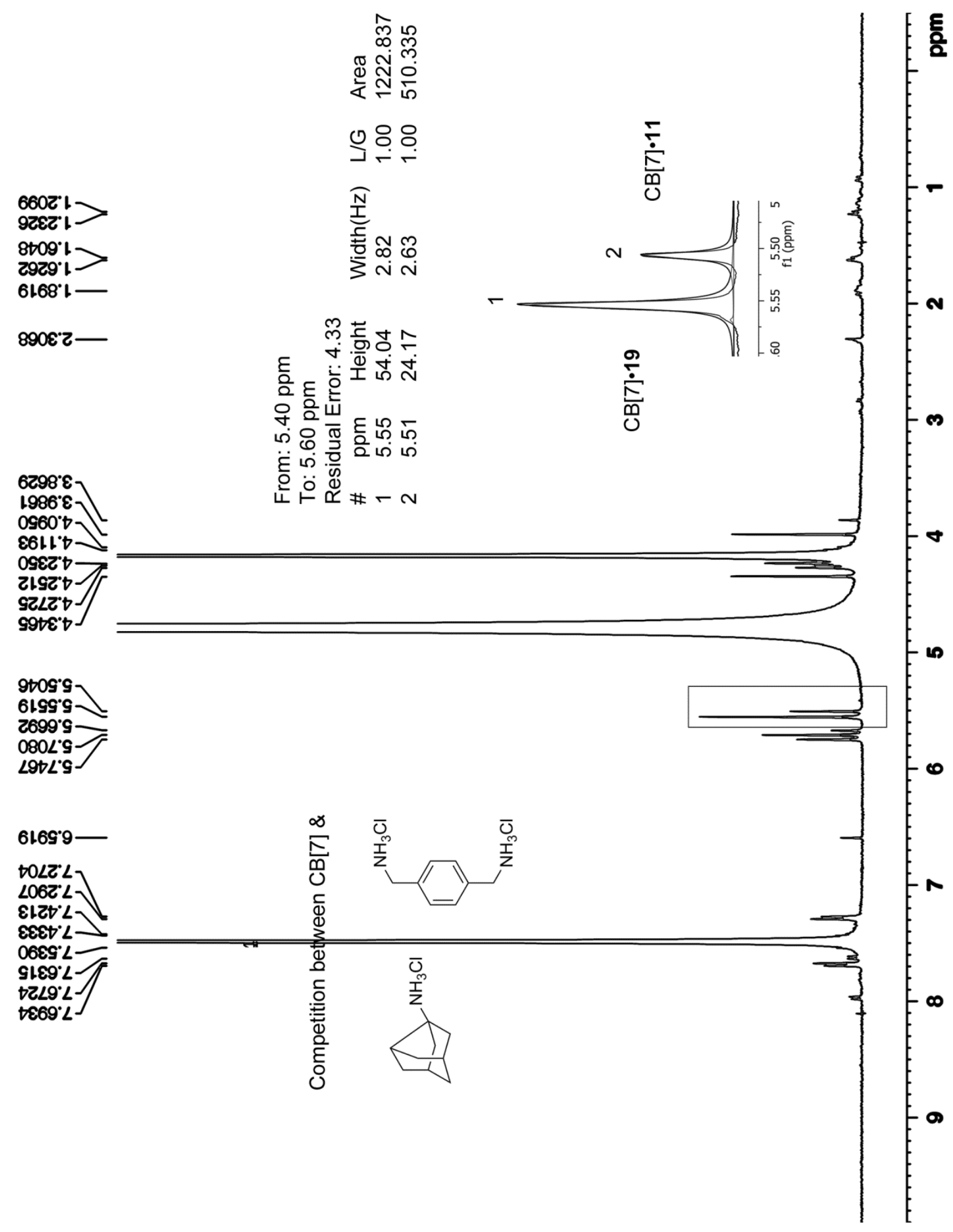

Figure S39. One of the ${ }^{1} \mathrm{H}$ NMR spectra (400 MHz, $\mathrm{D}_{2} \mathrm{O}, 100 \mathrm{mM} \mathrm{Na}{ }_{3} \mathrm{PO}_{4}$ buffer, $\mathrm{pH}=7.4$, rt) used in the determination of $\mathrm{K}_{\mathrm{rel}}$ for $\mathrm{CB}[7] \cdot 19$ and $\mathrm{CB}[7] \cdot \mathbf{1 1}$. $[\mathrm{CB}[7]]_{\text {Total }}=0.2608 \mathrm{mM}$, [19] Total $=0.3366 \mathrm{mM},[\mathbf{1 1}]_{\text {Total }}=79.5997 \mathrm{mM}$. 


\section{References}

1. Job, P. Ann. Chim., 1928, 9, 113-203. 